\title{
Ghrelin, a novel therapy, corrects cytokine and NF-KB-AKT-MAPK network and mitigates intestinal injury induced by combined radiation and skin-wound trauma
}

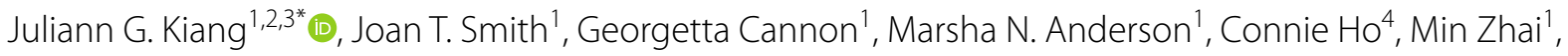
Wanchang Cui ${ }^{1}$ and Mang Xiao ${ }^{1}$

\begin{abstract}
Background: Compared to radiation injury alone (RI), radiation injury combined wound (Cl) further enhances acute radiation syndrome and subsequently mortality. We previously reported that therapy with Ghrelin, the 28-amino-acidpeptide secreted from the stomach, significantly increased 30-day survival and mitigated hematopoietic death by enhancing and sustaining granulocyte-colony stimulating factor (G-CSF) and keratinocyte chemoattractant (KC) in the blood and bone marrow; increasing circulating white blood cell depletion; inhibiting splenocytopenia; and accelerating skin-wound healing on day 30 after $\mathrm{Cl}$. Herein, we aimed to study the efficacy of Ghrelin on intestinal injury at early time points after $\mathrm{Cl}$.

Methods: B6D2F1/J female mice were exposed to ${ }^{60} \mathrm{Co}-\gamma$-photon radiation (9.5 Gy, $0.4 \mathrm{~Gy} / \mathrm{min}$, bilateral), followed by 15\% total-body-surface-area skin wounds. Several endpoints were measured: at 4-5 h and on days 1, 3, 7, and 15.

Results: Ghrelin therapy mitigated Cl-induced increases in IL-1 $\beta, I L-6, I L-17 A, I L-18, K C$, and TNF- in serum but sustained G-CSF, KC and MIP-1a increases in ileum. Histological analysis of ileum on day 15 showed that Ghrelin treatment mitigated ileum injury by increasing villus height, crypt depth and counts, as well as decreasing villus width and mucosal injury score. Ghrelin therapy increased AKT activation and ERK activation; suppressed JNK activation and caspase-3 activation in ileum; and reduced NF-KB, iNOS, BAX and BCl-2 in ileum. This therapy recovered the tight junction protein and mitigated bacterial translocation and lipopolysaccharides levels. The results suggest that the capacity of Ghrelin therapy to reduce Cl-induced ileum injury is mediated by a balanced NF-KB-AKT-MAPK network that leads to homeostasis of pro-inflammatory and anti-inflammatory cytokines.
\end{abstract}

Conclusions: Our novel results are the first to suggest that Ghrelin therapy effectively decreases intestinal injury after $\mathrm{Cl}$.

Keywords: lonizing radiation, Skin wound, Ghrelin, GI, NF-KB, AKT, ERK, JNK, MAPK, iNOS, BAX, BCl-2, Caspase, Tight junction, Apoptosis, Bacteria

*Correspondence: juliann.kiang@usuhs.edu

1 Scientific Research Department, Armed Forces Radiobiology Research Institute, Bethesda, MD 20814, USA

Full list of author information is available at the end of the article

\section{Background}

Victims from radiation exposure accidents and nuclear weapon detonations experience radiation injury (RI), and often concurrently with physical trauma, such as wounds, burns, blast and/or hemorrhage-thus inducing, namely, combined injury (CI). CI was observed following

c) The Author(s) 2020. This article is licensed under a Creative Commons Attribution 4.0 International License, which permits use, sharing, adaptation, distribution and reproduction in any medium or format, as long as you give appropriate credit to the original author(s) and the source, provide a link to the Creative Commons licence, and indicate if changes were made. The images or other third party material in this article are included in the article's Creative Commons licence, unless indicated otherwise in a credit line to the material. If material is not included in the article's Creative Commons licence and your intended use is not permitted by statutory regulation or exceeds the permitted use, you will need to obtain permission directly from the copyright holder. To view a copy of this licence, visit http://creativeco mmons.org/licenses/by/4.0/. The Creative Commons Public Domain Dedication waiver (http://creativecommons.org/publicdomain/ zero/1.0/) applies to the data made available in this article, unless otherwise stated in a credit line to the data. 
the atomic bombings in Hiroshima and Nagasaki, Japan, as well as at the Chernobyl reactor meltdown. $60-70 \%$ of victims [1-4] and 10\% of victims [5], respectively, received thermal burns alongside RI. Burns, wounds, infections, and hemorrhage typically increase mortality after otherwise non-lethal radiation doses observed in CI animal models, including mice [6-16], rats [17-19], guinea pigs [20], dogs [21, 22] and swine [23]. CI also delays wound closure times from normally 14-21 days after wounding without radiation to more than 30 days after irradiation $[6,9,10,24]$.

Altogether, CI leads to more severe outcomes than RI. CI has been observed to accelerate body-weight loss; amplify cytokine/chemokine imbalance and systemic bacterial infection [6, 16]; enhance leukocytopenia, thrombocytopenia, erythrocytopenia $[7,9,10,15]$, acute myelosuppression, immune system inhibition, fluid imbalance, macro- and microcirculation failure, massive cellular damage and disruption of vital organ functions. These subsequently led to multiple organ dysfunction (MOD) and multiple organ failure (MOF). Ultimately, death occurs as a result of CI $[1,20,25,26]$.

In our mouse model for $\mathrm{RI}$ and $\mathrm{CI}$, the $\mathrm{LD}_{50 / 30}$ for $\mathrm{RI}$ is 9.65 Gy, whereas radiation-wound $\mathrm{CI}(\mathrm{R}-\mathrm{W} \mathrm{CI})$ is $8.95 \mathrm{~Gy}$. The dose modifying factor (DMF) is 1.08 [6]. It is speculated that intervention of CI-induced aggravation of body-weight loss, cytokine imbalance or bacterial sepsis should improve the survival. Drugs or biologics such as pegylated G-CSF [9], Ciprofloxacin [10, 24], mesenchymal stem cells [27], and Ghrelin [28], prove to be effective for increasing 30-day survival.

The Ghrelin hormone is a hunger-stimulating peptide, containing 28 amino acids [29], produced mainly by P/ D1 cells lining the fundus of the human stomach and by epsilon cells of the pancreas [30]. Ghrelin levels increase before meals and decrease after meals. Its counterpart hormone, leptin, is produced by adipose tissue [31].

Ghrelin potently stimulates growth hormone from the anterior pituitary gland [29], and it also activates the endothelial isoform of nitric oxide synthase (eNOS) in a pathway [32] that depends on the PI3K/Akt/eNOS/NO signaling pathway [33, 34]. Ghrelin binds on growth hormone secretagogue receptors that are coupled to G-proteins [29].

It has been reported that human Ghrelin decreases organ injury and increases survival by $30 \%$ above vehicletreated mice after RI combined with severe sepsis in rats [18]. Kiang et al. [28] reported that Ghrelin therapy was efficacious in a mouse model of radiation combined with wounds or burns by increasing survival, body weight, wound healing, bone marrow cell counts, neutrophil recovery and platelet recovery on day 30 post-CI, as well as by inhibiting brain hemorrhage [35]. Ghrelin blocks
NF- $\mathrm{kB}$ activation, decreases TNF- $\alpha$ and IL- 6 concentrations in the lungs of septic rats, and inhibits nucleotidebinding oligomerization domain-containing protein 2 (NOD2, also known as caspase recruitment domaincontaining protein 15 (CARD15) or inflammatory bowel disease protein 1 (IBD1)\} [36]. NOD2 is important for apoptosis and NF- $\mathrm{kB}$ activation pathways [37]. Ghrelin inhibits IкB and increases Th1 cytokine and IL-17 secretion in primary T cells [38]. Furthermore, human Ghrelin mitigates jejunum injury and mortality after irradiation alone in rats [39]. We reported that Ghrelin mitigated CIinduced bone marrow damage by sustaining G-CSF and $\mathrm{KC}$ increases in bone marrow and circulation [40]. Other laboratories have demonstrated that Ghrelin suppresses inflammation and neuronal nitric oxide synthase [41]. However, Ghrelin's effects on CI-induced ileum injury were unclear and possible underlying mechanisms were not delineated either. Because RI and CI prominently induce increased production of inflammatory cytokines/ chemokines [6-8], the idea is that interventions mitigate inflammatory responses early on showing promise for improving ileum injury after CI. We, therefore, wanted to elucidate the dynamic changes in ileum cell death and its related signaling molecules. This report provides evidence from an experimental CI animal model, which was designed to demonstrate a kinetic change in Ghrelin effects at early time points after CI in ileum histopathology, circulating cytokines/chemokines, and apoptosis-related molecules including AKT-MAPK activation, NF- $\mathrm{kB}$, and iNOS.

\section{Methods}

\section{Experimental design}

B6D2F1/J female mice were randomly divided into 8 groups: (1) sham vehicle, (2) wound vehicle, (3) RI vehicle, (4) CI vehicle, (5) sham ghrelin, (6) wound ghrelin, (7) RI ghrelin, and (8) CI ghrelin. Groups 2, 4, 6 and 8 received topical gentamicin cream; groups 1-8 were administered with oral levofloxacin. $\mathrm{N}=6$ mice per group per time point. Hematological analysis, spleen weights, splenocyte counts, sternum histology and femur bone marrow cell counts of surviving animals were performed at each specified time point. The AFRRI Institutional Animal Care and Use Committee reviewed and approved all animal procedures. Euthanasia was carried out in accordance with the recommendations and guidance of the American Veterinary Medical Association $[42,43]$.

\section{Animals}

B6D2F1/J female mice (The Jackson Laboratory, Bar Harbor, ME) were maintained in a facility accredited by the Association for Assessment and Accreditation of 
Laboratory Animal Care International in plastic microisolator cages on hardwood chip bedding. Commercial rodent chow and acidified tap water were provided ad libitum at 12 to 20 weeks of age. Animal holding rooms were maintained at $21{ }^{\circ} \mathrm{C} \pm 1{ }^{\circ} \mathrm{C}$ with $50 \% \pm 10 \%$ relative humidity using at least 10 changes/h of $100 \%$ conditioned fresh air. A 12-h 0600 (light) to 1800 (dark) full-spectrum lighting cycle was used.

\section{Gamma irradiation}

Mice were given 9.5 Gy [7] whole-body bilateral ${ }^{60} \mathrm{Co}$ $\gamma$-photon radiation, delivered at a dose rate of $0.4 \mathrm{~Gy} /$ min, while held in vertically stacked, ventilated, fourcompartment, acrylic plastic boxes that provided electron equilibrium during irradiation. Mice were not anesthetized in boxes where they could move freely. Empty compartments within the boxes were filled with 3 -inch-long $\times 1$-inch-diameter acrylic phantoms to ensure uniform electron scattering. The mapping of the radiation field was performed with alanine/EPR dosimetry [44] using standard alanine calibration sets from the U.S. National Institute of Standards and Technology and National Physical Laboratory of the United Kingdom. The mapping provided dose rates to water measured by alanine pellets placed in the hollowed core of the acrylic phantoms in each compartment of the mouse rack on the day of the mapping. The field was uniform within $\pm 1.8 \%$ over all the 120 compartments. The exposure time for each irradiation dose was determined from the mapping data; corrections for the ${ }^{60} \mathrm{Co}$ decay and the small difference in the mass energy absorption coefficients for water and soft tissue were applied. The accuracy of the actual dose delivery was verified with an ionization chamber adjacent to the mouse rack, which had been calibrated in terms of dose to the mid-line soft tissue of mice.

\section{Skin injury}

Skin surface injuries were performed on the shaved dorsal surface of mice. Animals receiving skin wounds were anesthetized by isoflurane inhalation. A 15\% total body-surface-area skin wound was performed within $1 \mathrm{~h}$ after irradiation [6]. Briefly, an experimental wound was administered $19 \pm 1.3 \mathrm{~mm}$ from the occipital bone and between the scapulae using a stainless- steel punch on a Teflon-covered board cleaned with 70\% alcohol before each use. The anniculus carnosus muscle and overlying skin ( $23.5 \pm 1.1 \mathrm{~mm}$ long and $14.9 \pm 0.7 \mathrm{~mm}$ wide) were removed. All mice subjected to the skin injury were given $0.5 \mathrm{~mL}$ sterile $0.9 \% \mathrm{NaCl}$ intraperitoneally (i.p.), which contained $150 \mathrm{mg} / \mathrm{kg}$ of acetaminophen (AmerisourceBergen, Glen Alen, Virginia), immediately after skin injury to alleviate pain. The sham group received the same handling procedure except administration of $0.5 \mathrm{ml}$ sterile $0.9 \% \mathrm{NaCl}$ containing $150 \mathrm{mg} / \mathrm{kg}$ of acetaminophen.

\section{Ghrelin}

Ghrelin was purchased from Phoenix Pharmaceutical (Burlingame, CA). Three doses of $113 \mu \mathrm{g} / \mathrm{kg}$ were administered by lateral tail-vein injections [18] in a volume of $0.2 \mathrm{ml} 24 \mathrm{~h}, 48 \mathrm{~h}$ and $72 \mathrm{~h}$ after RI or CI. The doses of Ghrelin were derived from the previous publications [18, 39]. The vehicle given to control mice was sterile $0.9 \%$ sodium chloride solution for injection, USP.

\section{Antimicrobial agents}

Gentamicin sulfate cream, 0.1\% (generic, E. Fougera and Co., Melville, N.Y., NDC 0168-007-15), was applied daily for 10 days to the skin injuries on days 1-10. Levofloxacin (LVX), (generic, Aurobindo Pharma, Ltd., Mahaboob Nagar, India, NDC 65862-537-50), $100 \mathrm{mg} / \mathrm{kg}$ in $0.2 \mathrm{ml} /$ mouse, was administered p.o. daily for 14 days on days 3-16. Briefly, a 500-mg tablet was crushed by mortar and pestle. The LVX in the powder was dissolved in a volume of sterile water approximately one-third the total volume required to prepare the concentration needed for the average body mass of the mice to be treated. The mortar was rinsed with the remaining two-thirds volume of sterile water. The combined suspension was centrifuged to remove the particulate filler and the supernatant solution was passed through a $0.45-\mu \mathrm{m}$ membrane filter into a sterile amber bottle, which was sealed with a sterile rubber stopper and stored at $4-8{ }^{\circ} \mathrm{C}$ [9].

\section{Histopathology assessment}

Ileum specimens were collected from mice on day 15 ( $\mathrm{n}=6$ mice per group). Specimens were rinsed in cold saline solution and immediately fixed in $10 \%$ phosphatebuffered formalin. The tissue was then embedded in paraffin, sectioned transversely and stained with H\&E. The histology slides were scanned using Zeiss Axioscan.Z1. Then, villus height, villus width, crypt depth, and crypt numbers were counted and mucosal injury scores were assigned [45] using Zen 2 software (Zeiss Company, Thornwood, NY). To briefly summarize: grade $0=$ normal mucosa; grade $1=$ development of subepithelial spaces near the tips of the villi with capillary congestion; grade $2=$ extension of the subepithelial space with moderate epithelial lifting from the lamina propria; grade $3=$ significant epithelial lifting along the length of the villi with a few denuded villus tips; grade $4=$ denuded villi with exposed lamina propria, dilated capillaries and reduced crypt death and counts; and grade $5=$ disintegration of the lamina propria, hemorrhage, and ulceration. 


\section{Cell apoptosis measurement}

Ileum tissue slides were washed in three changes of xylene for $5 \mathrm{~min}$ each, in two changes of absolute ethanol for 5 min each, once in 95\% ethanol and once in 70\% ethanol for $3 \mathrm{~min}$ each and then once in PBS for $5 \mathrm{~min}$. To observe cell apoptosis, slides were stained using ApopTag $^{\circledR}$ Plus Peroxidase in Situ Apoptosis Detection Kit (EMD Millipore Corp, Temecula, CA) following the manufacturer's instructions.

\section{Measurement of cytokines/chemokines}

Blood samples were collected at $4-5 \mathrm{~h}$ and on days 1,3 , 7, and 15 after RI or $\mathrm{CI}(\mathrm{N}=6$ mice per group per time point) after RI or CI using BD Microtainers (Becton, Dickinson and Company, Franklin Lakes, NJ). Blood samples were placed at room temperature for $30 \mathrm{~min}$ and centrifuged at $9600 \times g$ for $10 \mathrm{~min}$ (Sovall Legend Micro 21 Centrifuge, Thermo Scientific). Then, serum was collected. Ileum samples were minced, blended with beads, homogenized with Bullet Blender Storm 24 (Averill Park, $\mathrm{NY}$ ), and centrifuged at $9600 \mathrm{xg}$ for $10 \mathrm{~min}$. The supernatants were collected. Cytokine/chemokine concentrations were measured and analyzed using the Bio-PlexTM Cytokine Assay (Bio-Rad; Hercules, CA) following the manufacturer's directions. Briefly, serum samples and tissue lysates from each animal were diluted fourfold and examined. Data were analyzed using the LuminexH 100TM System (Luminex Corp.; Austin, TX) and quantified using MiraiBio MasterPlexH CT and QT Software (Hitachi Software Engineering America Ltd.; San Francisco, CA), and concentrations were expressed in pg/ $\mathrm{mL}$ unless otherwise noted. The cytokines analyzed were IL-1 $\alpha$ IL-1 $\beta$, IL-2, IL-3, IL-4, IL-5, IL-6, IL-9, IL-10, IL12(p40), IL-12(p70), IL-13, IL-15, IL-17A, IL-18, eotaxin, G-CSF, GM-CSF, IFN-c, KC, MCP-1, MIP-1a, MIP-1b, MIP-2, RANTES and TNF-a. Data were expressed as pg/ $\mathrm{mL}$ in serum and $\mathrm{pg} / \mathrm{mg}$ protein in tissues [6].

\section{Tissue lysates}

Mice ( $\mathrm{N}=6$ per group) were anesthetized by isoflurane followed by vertebrate dislocation at different time points after RI and CI for blood collection and tissue collection. Their ileum were collected. The ileum samples were mixed with $\mathrm{Na}^{+}$Hanks' solution containing $10 \mu \mathrm{l} /$ $\mathrm{ml}$ protease inhibitor cocktail, $10 \mathrm{mM}$ phosphatase 2 inhibitor, $10 \mathrm{mM}$ phosphatase 3 inhibitor, $10 \mathrm{mM}$ DTT, $5 \mathrm{mM}$ EDTA and $10 \mathrm{mM}$ PMSF, homogenized using Bullet Blender Homogenizer Storm (Next Advance, Averill Park, NY) for 4 min at speed 10 and centrifuged at $9000 \mathrm{xg}$ for $10 \mathrm{~min}$ (Sorvall Legend Micro 21 Centrifuge, Thermo Electron Corp, Madison, WI). Supernatant fluids were conserved for protein determination and stored at $-80{ }^{\circ} \mathrm{C}$ until use.

\section{Western blot}

Total protein in the ileal lysates was determined with Bio-Rad reagent (Bio-Rad, Richmond, CA). Samples with $20 \mu \mathrm{g}$ of protein in $\mathrm{Na}^{+}$Hanks' buffer containing $1 \%$ sodium dodecyl sulfate (SDS) and 1\% 2-mercaptoethanol were resolved on SDS-polyacrylamide slab gels (Novex precast $4-20 \%$ gel, Invitrogen, Carlsbad, CA). After electrophoresis, proteins were blotted onto a polyvinylidene difluoride (PVDF) membrane $(0.45 \mu \mathrm{m}$, Invitrogene) using a Tran-Blot Turbo System and the manufacturer's protocol (Bio-Rad, Hercules, CA). The blot was then incubated for $90 \mathrm{~min}$ at room temperature with $5 \%$ non-fat dried milk in tris-buffered saline-0.5\% tween20 (TBST, $\mathrm{pH}=8.6$ ) at room temperature. After blocking, the blot was incubated with a selected antibody against NF-kBp65 (catalog no. 8008), iNOS (catalog no. sc7271), BAX (catalog no. sc20067), Bcl-2 (catalog no. sc7382) (Santa Cruz Biotechnology, Dallas, TX), AKT (catalog no. ab941263), p-AKT (catalog no. ab179463), ERK1/2 (catalog no. ab115799), p-ERK1/2 (catalog no. ab50011), JNK (catalog no. ab179461). P-JNK (catalog no. ab124956), p38 (catalog no. ab31828), p-p38 (catalog no. ab195049) (ABCAM, Cambridge, MA), Claudin 2 (catalog no. 32-5600) (Invitrogen, Waltham, MA) and IgG (catalog no. HAF008) (R \& D Systems, Minneapolis, $\mathrm{MN}$ ) at an approximately final concentration of 1-2 $\mu \mathrm{g} / \mathrm{ml}$ in TBST $-5 \%$ milk. The blot was washed 3 times (10 min each) in TBST before incubating for $60 \mathrm{~min}$ at room temperature with a $1000 \mathrm{X}$ dilution of species-specific IgG peroxidase conjugate (Santa Cruz, CA) in TBST. The blot was washed 6 times ( 5 min each) in TBST before detection of the peroxidase activity using the Enhanced Chemiluminescence kit (Amersham Life Science Products, Arlington Height, IL). IgG levels were not altered by radiation and were used as a control for protein loading. Protein bands of interest were quantitated using the ImageJ program and normalized to IgG. Data were expressed as intensity ratio to IgG levels [6].

\section{Ghrelin measurement}

Ghrelin in ileum lysate samples was measured using RayBio ${ }^{\circledR}$ Human/Rat Ghrelin Immunoassay Kit (RayBiotech, Norcross, GA) according to the manufacturer's protocol [46].

\section{Activated caspase-3 measurement}

Activated caspase-3 protein levels were measured using the Quantikine ELISA kit according to the manufacturer's protocol (R\&D SYSTEM, Minneapolis, MN).

\section{Bacterial translocation}

Bacterial translocation was determined as bacterial load in liver tissue and was quantified by real-time 
PCR using the 16S rRNA gene consensus sequence as described by Banerjee et al. [47]. The total load of bacteria in the liver was determined using primer sequences to amplify the highly conserved sequence for a broad species consensus. Livers were removed aseptically and stored at $-80{ }^{\circ} \mathrm{C}$ until use. Bacterial translocation was quantified by real-time PCR. Briefly, liver tissue was homogenized in a MP FastPrep 24 Instrument (MP biomedicals, Irvine, CA) using Green Bead Lysis kits (Next Advance, Troy, NY). DNA was isolated from liver lysates using a DNA purification kit (Promega, Madison, WI). Bacterial DNA and liver genomic DNA concentration were quantified using Quant-i $\mathrm{T}^{\mathrm{TM}}$ PicoGreen $^{\mathrm{TM}}$ dsDNA Assay Kit (Thermo Fisher Scientific, Waltham, MA). Serially diluted bacterial genomic DNA was used to generate the standard curve. Realtime PCR was performed using PowerUp SYBR green PCR master mix (Applied Biosystems, Foster City, CA) and $16 \mathrm{~S}$ rRNA gene targeted primers, forward $\left(5^{\prime}\right.$-ACT CCTACGGGAGGCAGCAGT-3') and reverse ( $5^{\prime}$-TAT TACCGCGGCTGCTGGC-3') in a QuantStudio 3 Realtime PCR System (Thermo Fisher Scientific, Waltham,
MA). PCR-derived bacterial counts were expressed as nanogram bacterial DNA per gram mouse liver tissue.

\section{Lipopolysaccharides measurement}

Lipopolysaccharides (LPS) levels were measured using LPS ELISA Kit (Antibodies-online.com, Catalog no. ABIN6574100) following the manufacturer's protocol.

\section{Statistical analysis}

Data are expressed as the mean \pm s.e.m. For each experiment, 6 mice per group were tested on an individual basis. One-way ANOVA, two-way ANOVA, studentizedrange test, and Student's $t$ test were used for comparison of groups, with $5 \%$ as a significant level.

\section{Results}

Ghrelin therapy inhibits circulating cytokines and chemokines after $\mathrm{RI}$ and $\mathrm{Cl}$

It is evident that RI alone induced increases in circulatory cytokines/chemokines and CI further induced the increases [6]. Figures 1, 2 and 3 show no changes in IL-1 $\beta$, IL-12p70, IL-15, IL-17A, IL-18, Eotaxin, GM-CSF and TNF- $\alpha 4-5 \mathrm{~h}$ after sham, wounding, RI and CI. However,

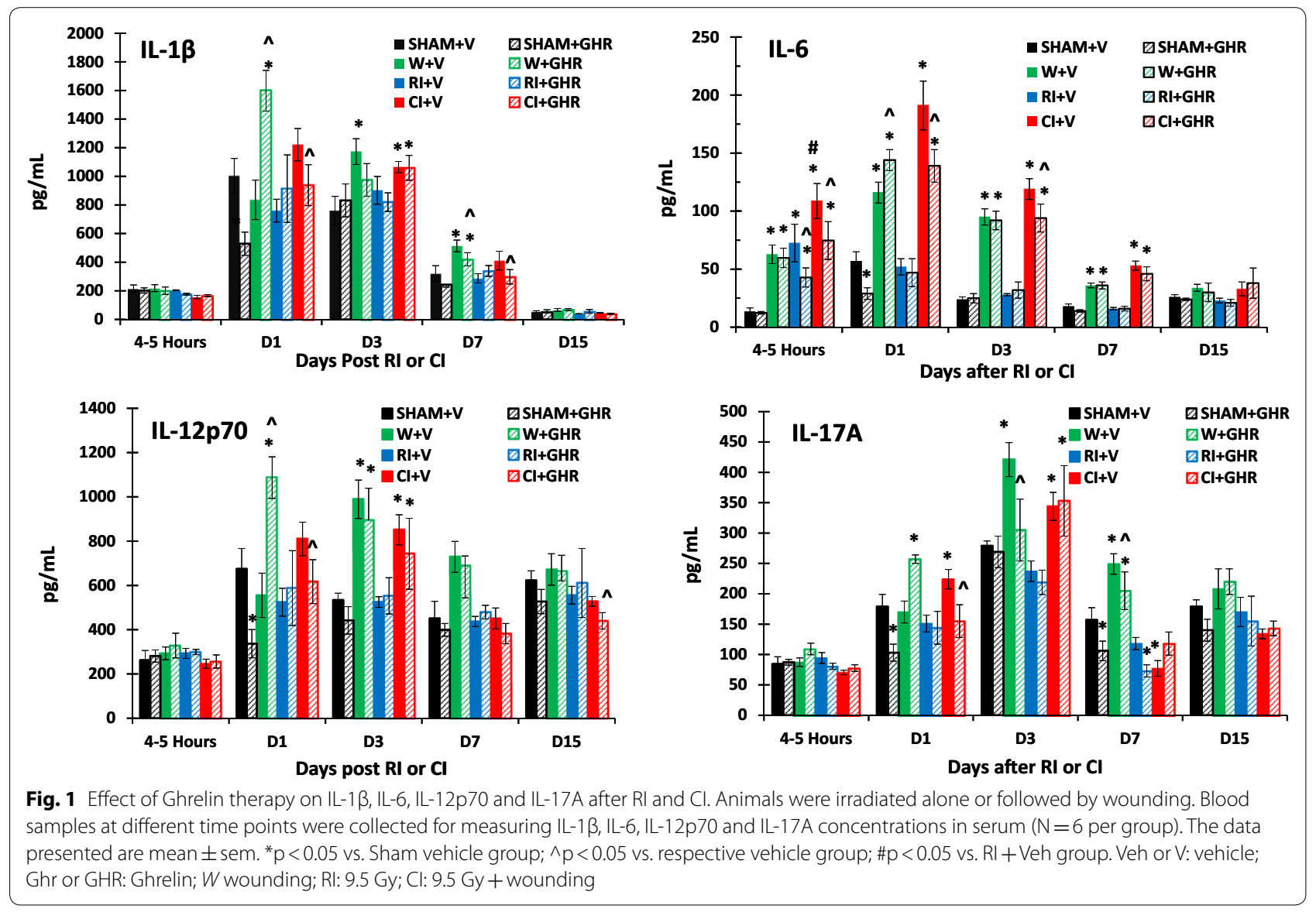



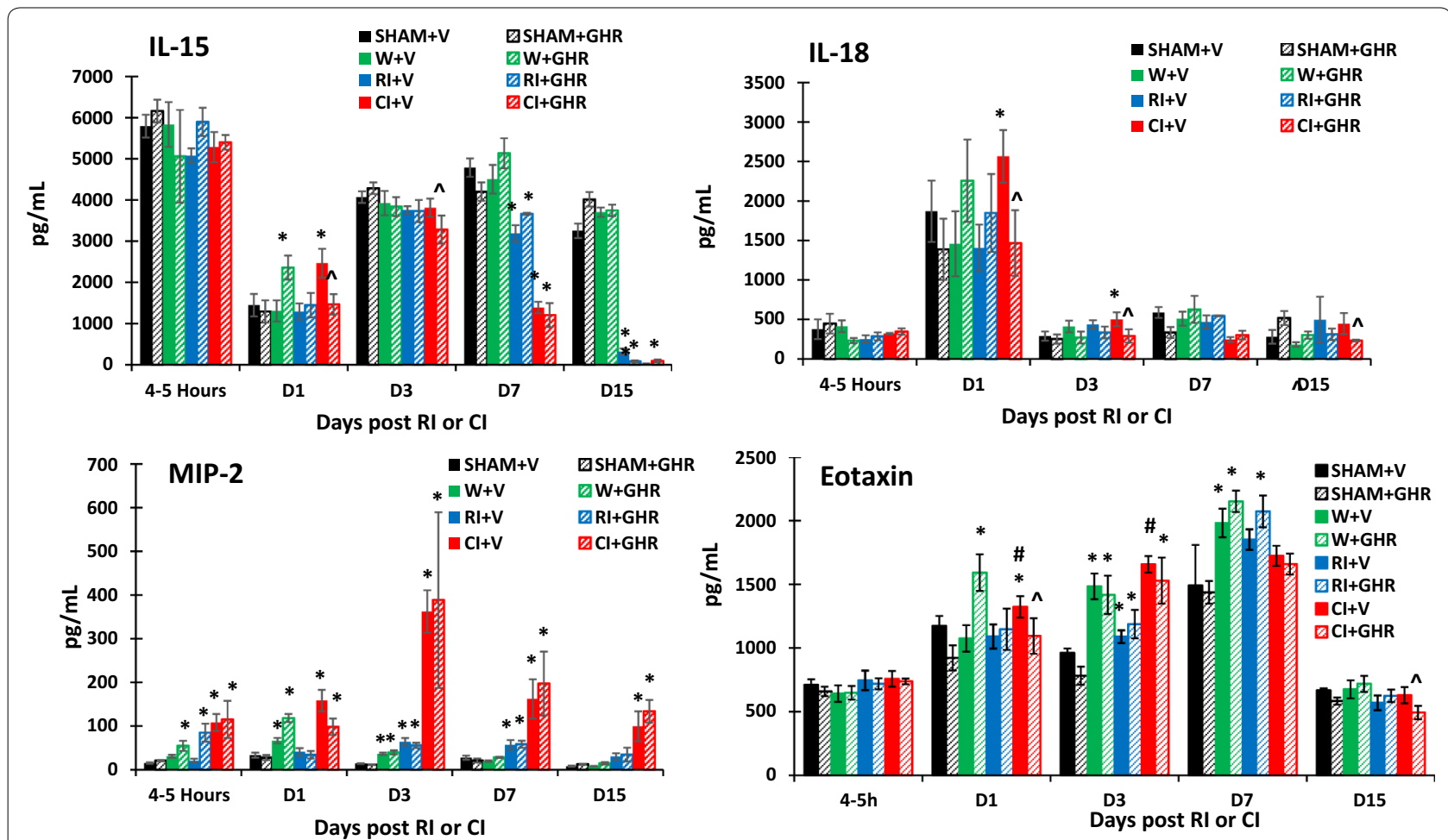

Fig. 2 Effect of Ghrelin therapy on IL-15, IL-18, MIP-2 and Eotaxin after RI and Cl. Animals were irradiated alone or followed by wounding. Blood samples at different time points were collected for measuring IL-15, IL-18, MIP-2 and Eotaxin A concentrations in serum (N=6 per group). The data presented are mean \pm sem. ${ }^{*} p<0.05$ vs. Sham vehicle group; $\wedge p<0.05$ vs. respective vehicle group; \#p $<0.05$ vs. RI $+V$ group. V vehicle, GHR Ghrelin, W wounding; RI: $9.5 \mathrm{~Gy}$; Cl: $9.5 \mathrm{~Gy}+$ wounding

wounding, RI, and CI increased IL-6, G-CSF, and KC. CIinduced increases were greater than RI-induced levels.

On day 1, wounding increased IL-6, G-CSF and KC; RI increased only $\mathrm{KC}$, whereas CI increased IL-6, IL-17A, IL-15, IL-18, MIP-2. G-CSF and KC. Treatment with Ghrelin further increased IL-1 $\beta$, IL-6, IL-12p70, IL-15, IL-17A, Eotaxin, GM-CSF, and TNF- $\alpha$ in wounded mice. In contrast, Ghrelin reduced RI-induced increases in KC and CI-induced increases in IL-1 $\beta$, IL-6, IL-12p70, Il-15, IL-17A, IL-18, MIP-2, Eotaxin, G-CSF, GM-CSF, KC and TNF- $\alpha$ in blood.

On day 3, wounding and CI increased IL-1 $\beta$, IL-6, IL12p70, IL-17, Eotaxin, G-CSF, GM-CSF, KC, and TNF- $\alpha$ in blood, whereas RI increased only G-CSF and $\mathrm{KC}$ in blood. Treatment with Ghrelin did not alter wound- and RI-induced increases in cytokines mentioned above on this day, but attenuated CI-induced increases in IL-6, IL-15 and IL-18 in blood.

On day 7 , wounding still increased IL-1 $\beta$, IL-6, IL12p70, IL-17A, Eotaxin, and TNF- $\alpha$, RI only increased MIP-2. CI still increased IL-1 $\beta$, IL-6, MIP-2, G-CSF and KC. Treatment with Ghrelin attenuated only IL- $1 \beta$ in blood of wounded and CI mice. CI-induced increases in IL-6, G-CSF and KC were not altered by Ghrelin.
On day 15, IL-1 $\beta$, IL-6, IL-17A and GM-CSF returned to their baselines. Ghrelin treatment dropped IL-12p70, IL-18, Eotaxin and TNF- $\alpha$ below their baselines only in the blood of $\mathrm{CI}$ mice, while further increasing circulating MIP-2, G-CSF and KC in these CI mice.

\section{Ghrelin therapy decreases IL-18 levels after RI and CI in ileum}

Because RI- [48] and CI- [16] induced increases in IL-18 concentrations in the blood were significantly attenuated by Ghrelin, IL-18 concentrations in tissues were measured. Figure 4 shows the presence of IL-18 detected in ileum, a radiation-sensitive organ. Wounding did not alter IL-18 basal levels on day 3 and day 7 but significantly increased IL-18 on day 15 . RI increased IL-18 on days 7 and 15; CI increased IL-18 only on day 7. Ghrelin therapy increased IL-18 in ileum of sham and wounded mice but not RI and CI mice on day 3. On day 7, Ghrelin therapy significantly attenuated IL- 18 below the basal levels in ileum of sham, wounded, RI, and CI mice. On day 15 , Ghrelin therapy reduced IL-18 concentrations in ileum of wounded and RI mice. IL-18 returned to basal levels in ileum of Ghrelin- or vehicle-treated CI mice. 

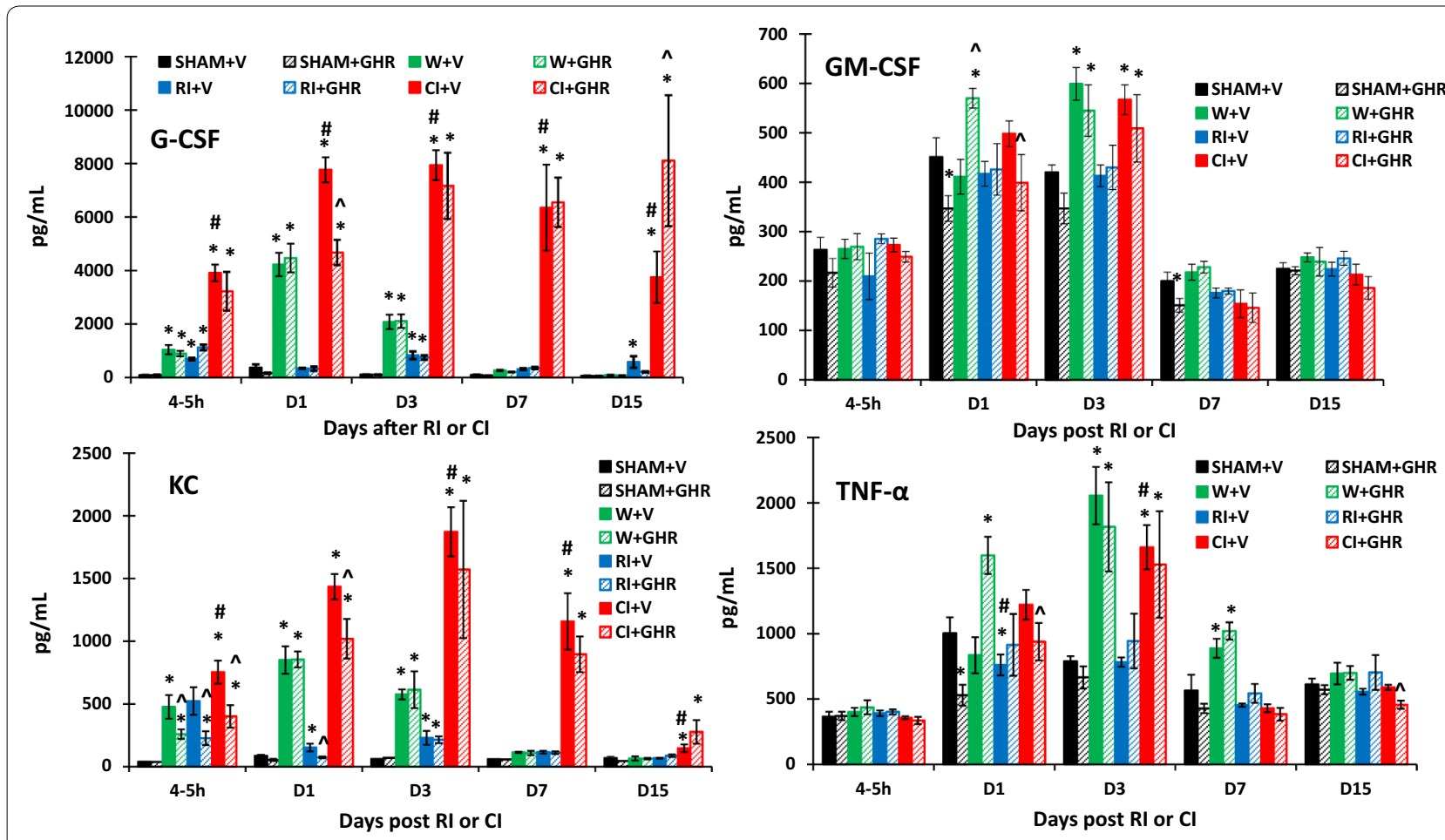

Fig. 3 Effect of Ghrelin therapy on G-CSF, GM-CSF, KC and TNF-a after RI and Cl. Animals were irradiated alone or followed by wounding. Blood samples at different time points were collected for measuring G-CSF, GM-CSF, KC and TNF-a concentrations in serum ( $N=6$ per group). The data presented are mean \pm sem. ${ }^{*} p<0.05$ vs. Sham vehicle group; $\wedge p<0.05$ vs. respective vehicle group; $\# p<0.05$ vs. RI $+V$ group. $V$ vehicle, GHR Ghrelin, W wounding; Rl: $9.5 \mathrm{~Gy} ; \mathrm{Cl}: 9.5 \mathrm{~Gy}+$ wounding

\section{Ghrelin therapy increases and sustains G-CSF levels after $\mathrm{Cl}$, as well as $\mathrm{KC}$ and MIP-1 1 levels after $\mathrm{RI}$ and $\mathrm{Cl}$ in ileum}

On day 7, CI-induced increases in G-CSF and MIP- $1 \alpha$ were further increased by Ghrelin (Fig. 4b, d). Increases in $\mathrm{KC}$ were also sustained in the presence of Ghrelin (Fig. 4c). The ghrelin levels in ileum lysate samples were also measured. As shown in Fig. 4e, RI tended to decrease ghrelin in ileum and Ghrelin therapy returned it to the basal level of sham animals. CI significantly decreased ghrelin levels in ileum, whereas the Ghrelin therapy recovered it to levels similar to those of the sham group.

\section{Ghrelin therapy recovers villus height, villus width, crypt depth and crypt count of ileum after $\mathrm{RI}$ and $\mathrm{Cl}$}

It is evident that RI and CI cause GI injury [1]. Ileum histology analysis was performed with $H \& E$ staining. Figure 5 shows that RI and CI injured the ileum morphology and Ghrelin therapy mitigated the injury (Fig. 5a). RI and $\mathrm{CI}$ increased the villus height (Fig. 5b) and width (Fig. 5c), as well as caused significantly shallower crypt depths (Fig. 5d) and lower crypt counts (Fig. 5e) compared to the sham group. Ghrelin therapy mitigated all of these changes (Fig. 5a-e). In addition, RI and CI increased mucosal injury scores, based on the criteria described in the Materials and Methods section above, that were reduced in CI mice after Ghrelin therapy (Fig. 5f).

\section{Ghrelin therapy decreases cell apoptosis and caspase-3 activation in ileum after $\mathrm{RI}$ and $\mathrm{Cl}$}

It is evident that RI [49] and CI [16] increase caspase-3 activation, which generally leads to cell apoptosis $[1,50]$. Therefore, we performed an apoptosis assay to compare apoptotic cell death. In Fig. 6a, b. RI on day 15 significantly induced apoptotic death in crypts and CI further increased the number of cell death. However, Ghrelin therapy mitigated the cell death in CI ileum samples.

We also measured caspase-3 levels in ileum in order to verify whether cell apoptosis was involved in RI- and CI-induced ileum damage. We demonstrate that on day 1 , caspase- 3 activation was unchanged by wounding, RI and CI with vehicle treatment, compared to sham mice. Treatment with Ghrelin, however, significantly reduced caspase-3 activation in these wounded, RI and CI mice (Fig. 6c). On day 3, similar observations were found in ileum samples of vehicle-treated mice. Ghrelin significantly reduced caspase- 3 levels in sham, wounded, and CI mice (Fig. 6d). On day 15, CI but not wounding and 


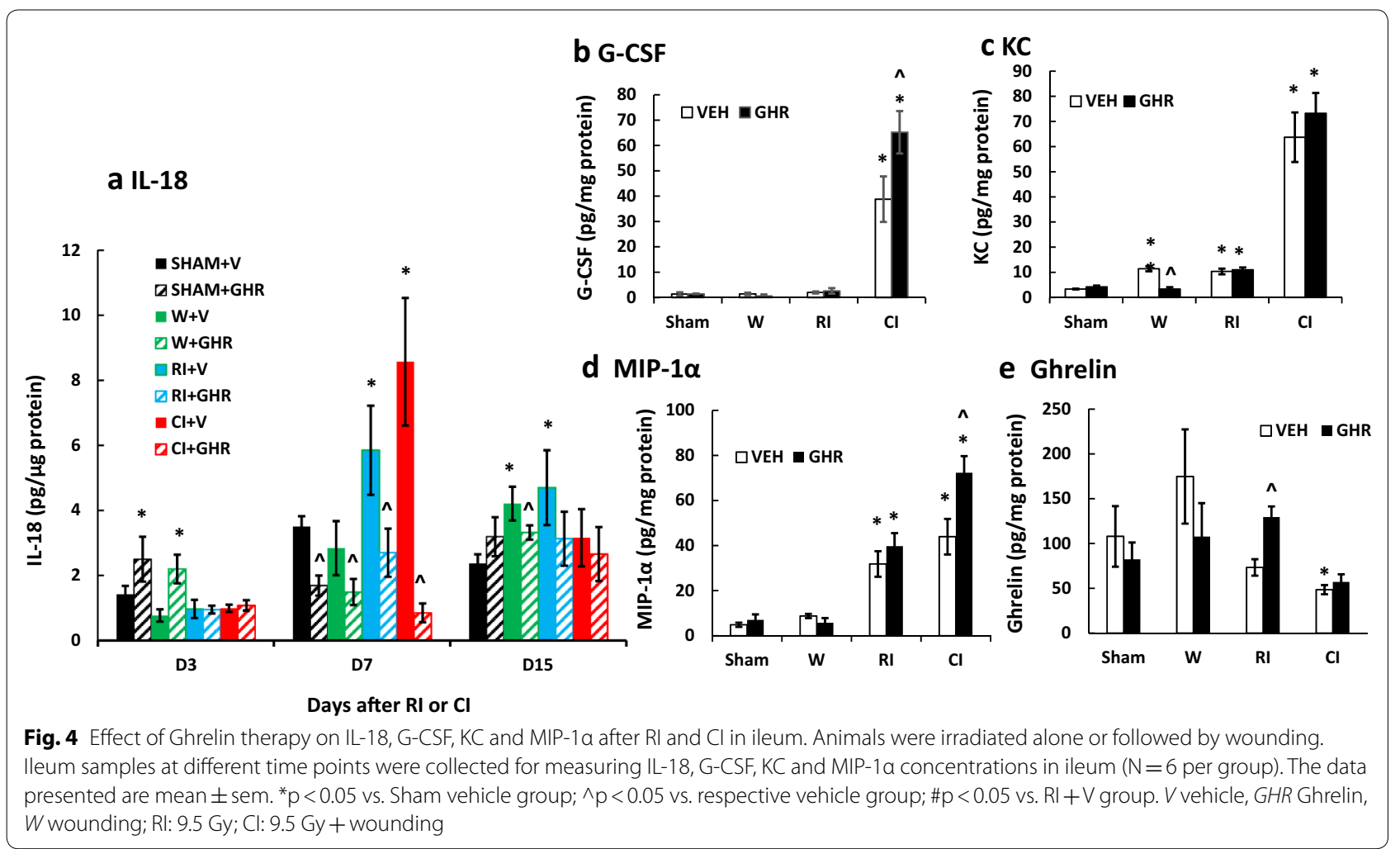

RI remarkably increased caspase- 3 activation, but the increase was able to be inhibited by Ghrelin (Fig. 6e).

\section{Ghrelin increases AKT and ERK activation after $\mathrm{Cl}$} and decreases JNK activation after wounding and RI RI and CI alter AKT and MAPK activation [16] which regulate cell apoptosis $[1,51]$. To evaluate whether Ghrelin altered their RI- and CI-induced changes, we measured them using Western blotting analysis. Figure 7 shows that AKT and phosphorylated AKT in ileum samples of vehicle-treated sham, wounded, RI, and CI mice on day 3 were similar, while AKT was reduced in Ghrelin-treated RI mice and increased in Ghrelin-treated CI mice (Fig. 7b). AKT phosphorylation was increased as well in CI mice treated with Ghrelin (Fig. 7c).

Figure 8 depicts that wounding, RI, and CI did not alter the basal levels of ERK phosphorylation (p-ERK), whereas Ghrelin increased p-ERK after CI. RI decreased JNK phosphorylation (p-JNK), but Ghrelin significantly decreased p-JNK in wounded and RI mice. Phosphorylated p38 was not altered in wounded, RI, and CI mice treated with vehicle or Ghrelin.

\section{Ghrelin decreases NF-KB, iNOS, BAX and Bcl-2 after $\mathrm{Cl}$}

Cell apoptosis is known to be initiated by increases in iNOS $[1,49,50]$, which is transcribed by NF-kB [6].
Therefore, we first investigated NF- $\mathrm{BB}$ in ileum lysate samples on day 3 . In vehicle-treated mice, wounding did not alter the basal expression of NF- $\mathrm{kB}$ as compared to the sham group. However, RI drastically increased NF- $\kappa B$, while CI further increased it. Ghrelin reduced the levels of this transcription factor in sham and $\mathrm{CI}$ mice, compared to their respective vehicle groups. However, Ghrelin therapy increased additional NF- $\mathrm{kB}$ in RI mice (Fig. 9a, b). Then, we measured iNOS (Fig. 9a, c). In vehicle-treated mice, wounding altered the basal expression of iNOS compared to the sham group. Nonetheless, RI significantly increased iNOS protein and CI increased even more iNOS than RI. Ghrelin therapy increased iNOS in sham mice and reduced iNOS protein in wounded mice and CI mice but not in RI mice.

Ghrelin was found to reduce BAX (a pro-apoptotic protein) and increase Bcl-2 (an anti-apoptotic protein) in a chronic liver injury model [28]. We, therefore, measured BAX and Bcl-2 in ileum on day 3 after RI and CI. Wounding significantly increased BAX, but CI significantly decreased BAX. Ghrelin therapy significantly increased BAX in sham samples but significantly decreased BAX in wounding samples and CI samples, whereas it did not alter RI-induced decreases in BAX (Fig. 9a, d).

In Fig. 9a, there were $2 \mathrm{Bcl}-2$ bands found very close to each other at $26 \mathrm{kDa}$. We assumed the lower band 


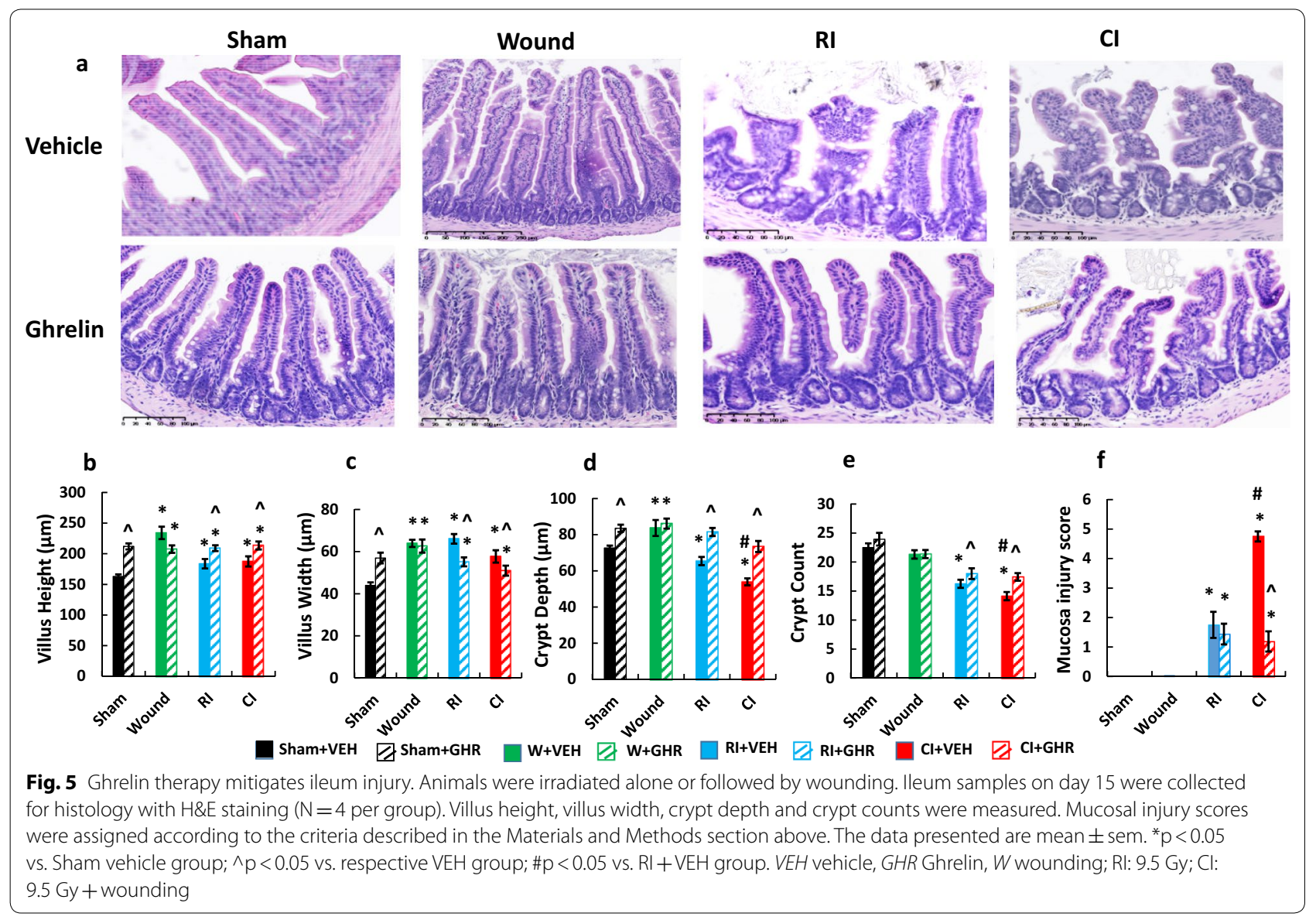

being unphosphorylated $\mathrm{Bcl}-2$ and the upper band being phosphorylated Bcl-2. Both bands were altered together. Therefore, we measured two bands together with ImageJ. Bcl-2 was decreased in wounding samples (lane 2), RI samples (land 3) and CI samples (lane 4) on day 3. Ghrelin therapy significantly increased both unphosphorylated and phosphorylated Bcl-2 bands in sham samples (lane 5), but significantly decreased both Bcl-2 bands in RI samples (lane 7) and CI samples [(lane 8) Fig. 9e]. The ratio of $\mathrm{BAX}$ to $\mathrm{Bcl}-2$ (total of unphosphorylated band and phosphorylated band) was increased in sham, RI and CI samples while it was decreased in wounded samples (Fig. 9f).

\section{Ghrelin increases tight junction protein after $\mathrm{Cl}$}

Functional assays of small intestinal injury include permeability [52]. Radiation is known to decrease tight junction protein in small intestine resulting in leakage [47]. Therefore, tight junction biomarker claudin 2 was measured in ileum samples on day 7 using Western blot analysis. Figure 10a depicts that RI significantly decreased claudin 2 by $44 \%(\mathrm{p}<0.05)$, while CI further decreased it by $72 \%(\mathrm{p}<0.005)$ compared to the basal level of sham samples. Ghrelin therapy recovered claudin 2 to the basal level in CI samples, whereas it remained low in the RI samples.

\section{Ghrelin attenuates bacterial translocation after $\mathrm{Cl}$}

Decreases in the tight junction in ileum allow passage of bacteria present in the lumen into the blood stream, and subsequently translocation to tissues that should be sterile [39, 47]. In the vehicle-treated animals, $16 \mathrm{~S}$ rRNA gene, a measure of bacterial counts, was significantly risen by $190 \%$ ( $p<0.05$ vs. Sham + VEH) and $180 \%$ $(\mathrm{p}<0.05$ vs. Sham $+\mathrm{VEH})$, respectively. Ghrelin therapy increased the basal level, but RI and CI only increased the bacterial counts by $24.7 \%$ ( $>0.05$ vs. Sham + GHR) and $24.3 \%$ ( $>0.05$ vs. Sham + GHR), respectively (Fig. 10b).

\section{Ghrelin attenuates lipopolysaccharides level after $\mathrm{Cl}$}

LPS levels represents the presence of Gram-negative bacteria. As shown in Fig. 10c, in the vehicle-treated animals, LPS levels in liver samples of wounded mice and CI mice on day 7 were significantly increased by $257 \%(\mathrm{p}<0.05$ vs. Sham + VEH) and $279 \%(\mathrm{p}<0.05$ vs. Sham + VEH), respectively, whereas. RI did not significantly increase it 

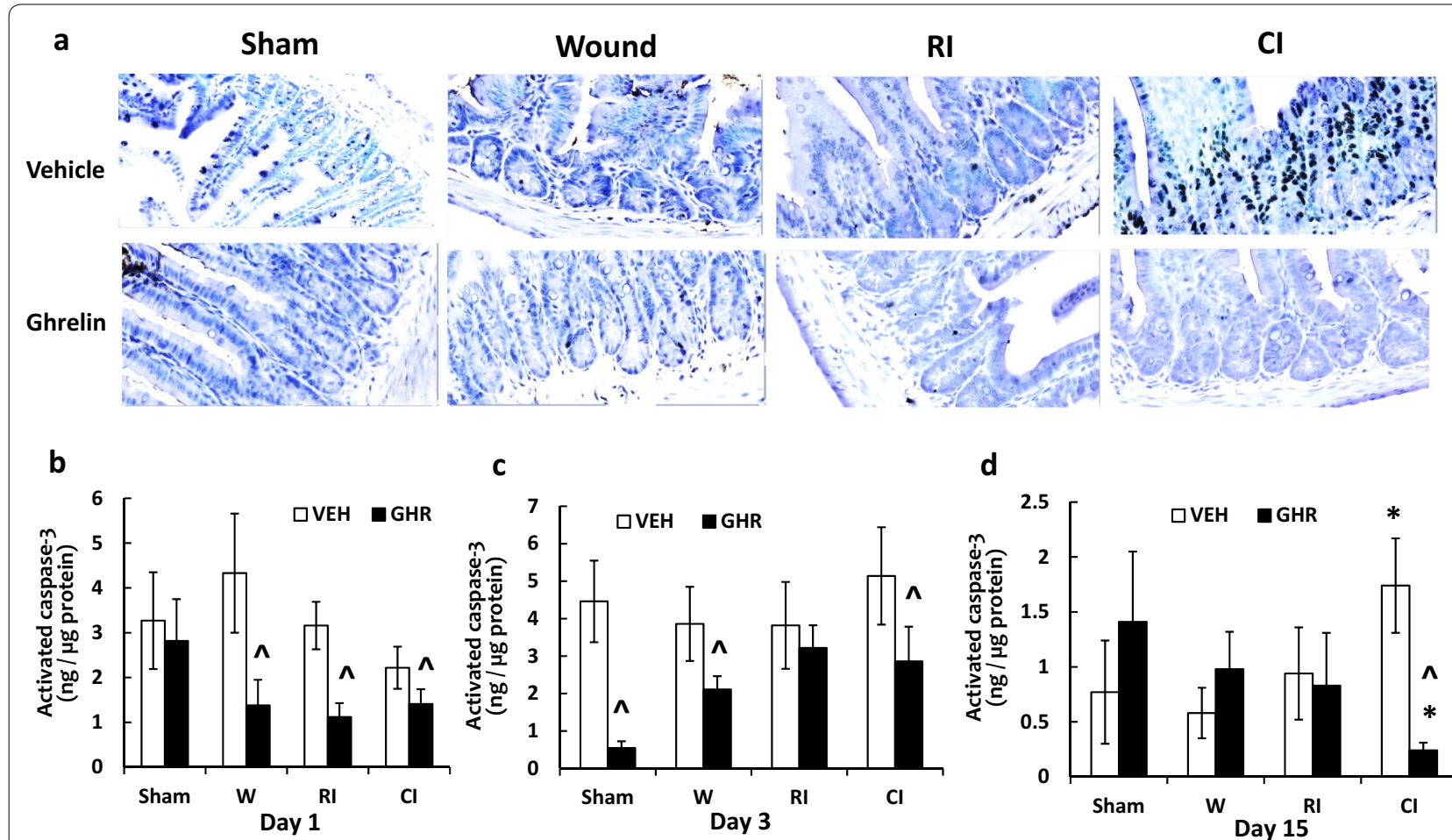

C
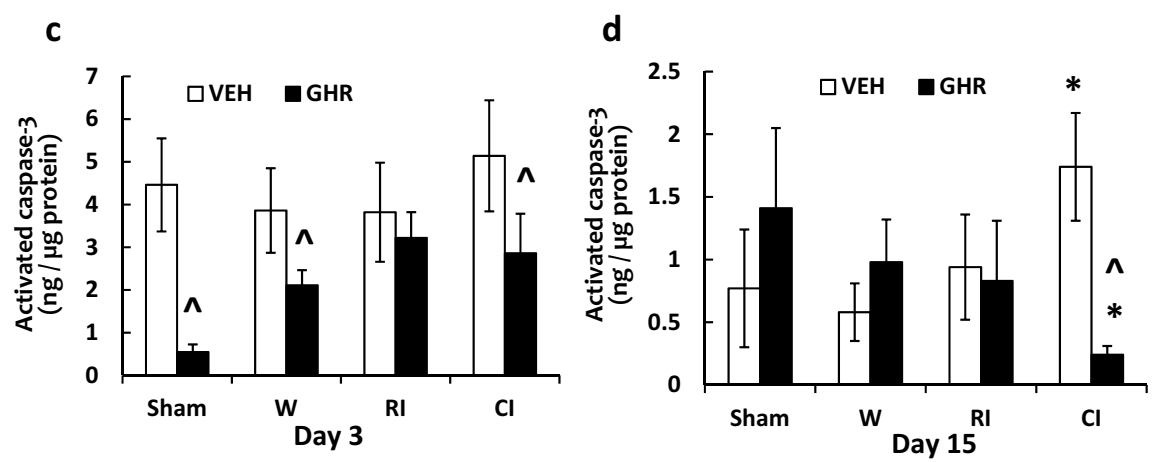

Fig. 6 Ghrelin therapy decreases cell apoptosis and caspase-3 activation in ileum. Animals were irradiated alone or followed by wounding. A Slides from ileum samples from day 15 were stained for apoptosis assessment. The representative slides for each group are presented. B The apoptotic cells per crypt were counted. C-E lleum samples at different time points were collected for measuring caspase-3 activation ( $N=6$ per group). The data presented are mean \pm sem. * $p<0.05$ vs. Sham VEH group; $\wedge p<0.05$ vs. respective VEH group. VEH vehicle, GHR Ghrelin, W wounding; Rl: 9.5 Gy; Cl: $9.5 \mathrm{~Gy}+$ wounding

(Fig. 10c). Ghrelin therapy effectively mitigated these LPS increases in RI and CI mice.

\section{Discussion}

Our novel results are the first to show that Ghrelin therapy mitigates ileum injury caused by CI. Therapy with Ghrelin, a stomach-derived peptide with a half-life of approximately $31 \mathrm{~min}$ in plasma [15, 44], significantly increased and sustained G-CSF levels after CI. Ghrelin therapy also led to KC and MIP- $1 \alpha$ increases after RI and $\mathrm{CI}$, in addition to reduce IL-18 in RI and CI mice. Ghrelin therapy ameliorated ileum injury, likely due to its ability to alter cytokines and chemokines in blood and ileum.

The circulating G-CSF increase significantly contributed to ileum, spleen, kidney, bone marrow and likely other untested organs [1]. In the bone marrow, it is known to stimulate myeloid progenitors for neutrophil proliferation and maturation [1]. Herein, we also found that, in ileum, CI significantly increased G-CSF with Ghrelin therapy further increasing it. The sustaining G-CSF in blood and its further increases in ileum probably provided significantly therapeutic effects to ileum. It was reported that, in mice, heart diabetes increased microRNA-34a levels in cardiomyocytes which then inhibited Bcl-2 levels and increased apoptosis. Increases in G-CSF inhibited microRNA-34a and reduced cell apoptosis in the heart [53]. We also reported that pegylated G-CSF combined with a thrombopoietin receptor agonist effectively mitigated ileum injury [45]. In this report, decreases in BAX and Bcl-2 levels were found in ileum samples of RI and CI mice and Ghrelin therapy further decreased $\mathrm{BAX}$ in $\mathrm{CI}$ mice and $\mathrm{Bcl}-2$ in $\mathrm{RI}$ and $\mathrm{CI}$ mice. The results agree with the observation found in a chronic liver injury model [32]. In contrast to the hearts of diabetic mice [53], we have detected RI and CI-induced increases in miR-34a (16), but Ghrelin therapy failed to inhibit these increases (Kiang et al., unpublished data). Decreases in Bcl-2 are indeed unfavorable in this case. Instead, decreases in BAX are beneficial and likely contribute to the mitigation of ileum injury [54].

$\mathrm{CI}$ significantly increased $\mathrm{KC}$ in blood and ileum. Ghrelin therapy maintained its levels above basal levels. Mainly produced by macrophages, neutrophils and epithelial cells $[55,56], \mathrm{KC}$ has been shown to be critical for wound healing. Ghrelin therapy recovered bone marrow cellularity on days 1,7 , and 15 and circulating neutrophils 

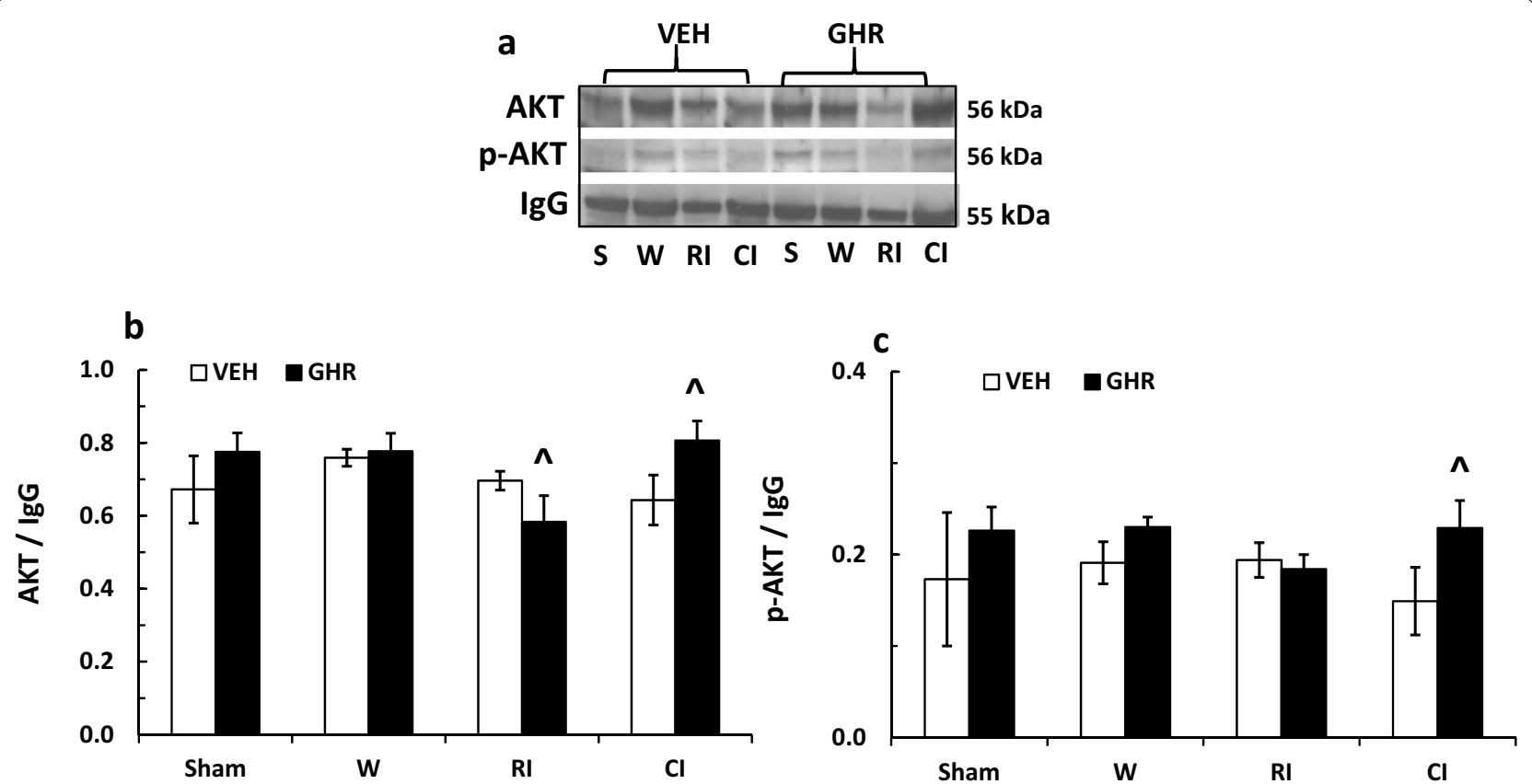

Fig. 7 Ghrelin therapy increases AKT activation in ileum. Animals were irradiated alone or followed by wounding. Ileum samples collected on day 3 were analyzed for AKT activation ( $N=4$ per group). The data presented are mean \pm sem. $\wedge p<0.05$ vs. respective VEH group. VEH vehicle, GHR Ghrelin, W wounding; Rl: 9.5 Gy; Cl: 9.5 Gy+ wounding

on days 3 and 15 [28]. Therefore, KC attracting neutrophils to the wound area for wound repair becomes very significant. In $\mathrm{KC}$ receptor knockout mice, wound healing was significantly delayed compared to wild type mice [57], suggesting no involvement with neutrophils. Therefore, maintenance of high levels of $\mathrm{KC}$ is significantly beneficial towards repairing ileum injury.

CI increased IL-18 in blood and ileum, maintaining consistency with our previous observations $[6,39]$. Ghrelin therapy significantly decreased IL-18 in blood and ileum. Mainly produced by macrophages, epithelial cells, and endothelial cells, IL-18 upregulates IFN-r and induces inflammation. It is associated with Alzheimer's disease and diabetic nephropathy [58, 59]. Therefore, Ghrelin inhibition of IL-18 was desired in this case. IL-18 binding protein has been shown to increase mouse survival after lethal irradiation [60]. There is no report yet suggesting treatment with IL-18 binding protein enables to improve survival after CI. However, Ghrelin therapy further increased MIP-1 $\alpha$ increases in ileum after RI and CI. MIP- $1 \alpha$ is known to promote homeostasis [61].

The classical histological end point in mice is the number of regenerating crypts measured in the small intestine at 3.5 days after RI [52]. Our previous publications indicated that the morphology changes in small intestine of B6D2F1 mice exposed to either RI or CI could not be clearly distinguished at 3.5 days. However, differences began to show at 7 days, with clear separation by days 15 and 30, in which CI induced more detrimental effects than RI [1]. Therefore, we adopted ileum tissues on day 15 for studying the histological end point. Once again, RI and $\mathrm{CI}$ resulted in fewer crypt counts and smaller crypts in ileum, while Ghrelin therapy enabled the mitigation of the crypt loss (Fig. 5a, d, e). The observations were consistent with those found in other laboratories [39].

Caspase- 3 is a critical protease in caspase-dependent apoptosis $[62,63]$ that increases in ileum following irradiation and combined injury $[6,16]$. Herein, RI and CI increased caspase-3 activation, which agrees with our previous observations $[6,16]$. Increases in capase- 3 activation above basal levels were observed on day 15, suggesting that apoptosis occurred later. This observation was reinforced with data obtained from apoptosis assay in situ (Fig. 6a, b).

Ghrelin, in general, binds to GHSR- $1 \alpha$ ghrelin receptors, coupling to $\mathrm{G}$ proteins. Ghrelin may have acted via mediation of the AKT/NOS/NO signal pathway [34] to ameliorate ileum injury. Ghrelin increased AKT phosphorylation and decreased JNK/MAPK phosphorylation in ileum of CI mice. In this strain of mice, CI did not change the basal levels of AKT and MAPK activation in ileum, but in the brain, CI decreased AKT, ERK/MAPK 


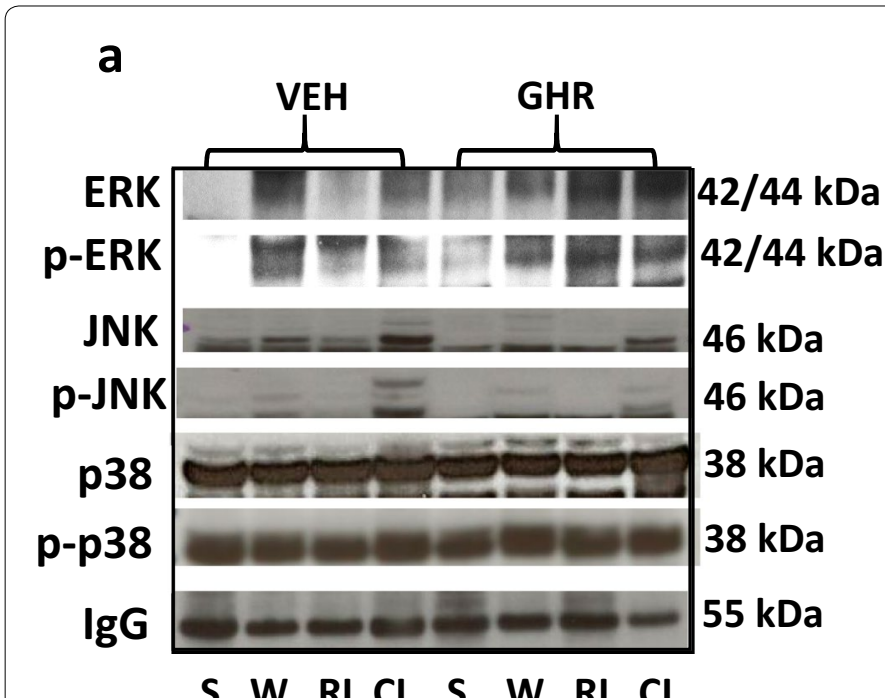

\section{b}

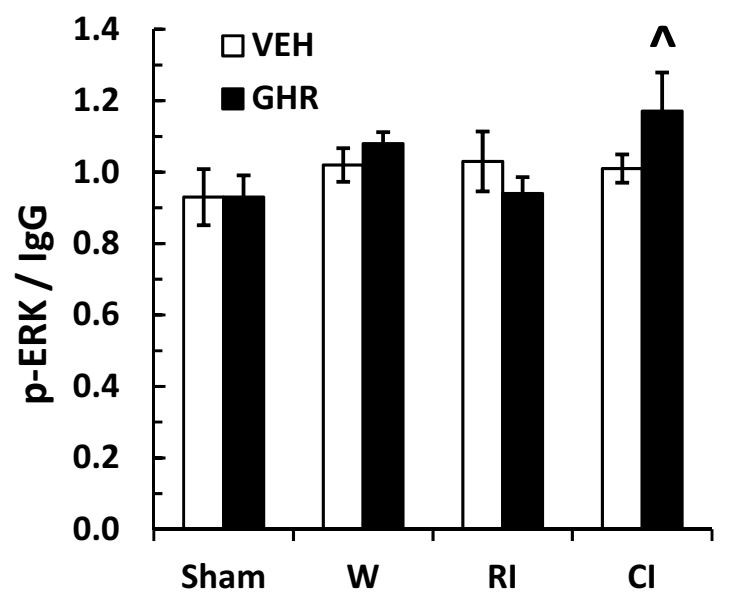

C

d
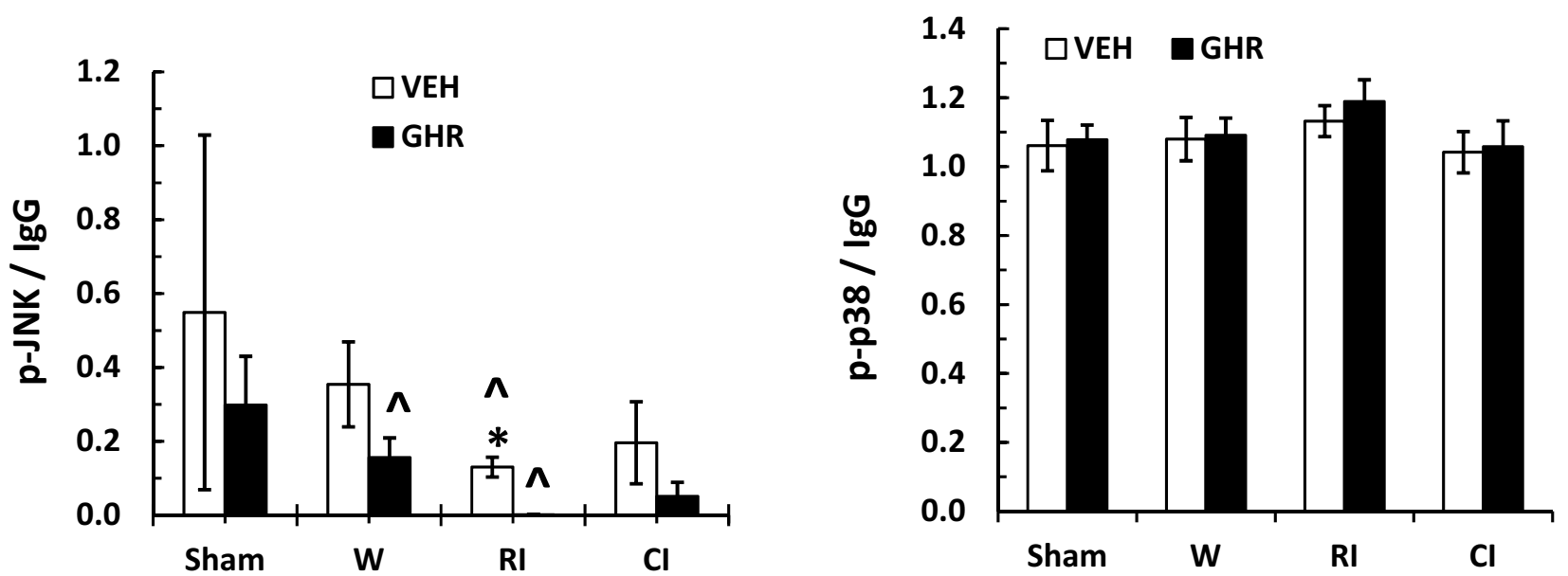

Fig. 8 Ghrelin therapy increases ERK activation and decreases JNK activation in ileum. Animals were irradiated alone or followed by wounding. lleum samples collected on day 3 were analyzed for AKT activation ( $N=4$ per group). The data presented are mean \pm sem. $\wedge p<0.05$ vs. respective VEH group. VEH vehicle, GHR Ghrelin, W wounding; RI: 9.5 Gy; Cl: 9.5 Gy + wounding

and JNK/MAPK activation [64]. This is inconsistent with observations found in CD2F1 mice, in which CI significantly increased ERK/MAPK and p38/MAPK activation in ileum [16]. Therefore, it is worthwhile to bear in mind that different strains of mice may respond to CI differently. Likewise, even within the same strain of mice, different organs may manifest different responses to CI. However, taken together, the data purport that resuming AKT activation by any means is critical for organ recovery and survival improvement $[1,51]$.

AKT activation triggers cell survival by regulating $N F-\kappa B[6,51]$. Although it was reported that NF-kB was required for AKT activation and that it resided upstream of AKT activation [65], it is evident that AKT activation was required for stimulating NF- $\mathrm{kB}$ [66-68]. Herein, we observed that $\mathrm{CI}$ did not alter the basal levels of AKT activation, but increased NF- $\mathrm{B}$ p65, the transcription factor for IL-1, IL-8, IL-18, IL-33, TNF and Trail gene expression [51]. However, Ghrelin therapy increased AKT activation while reducing NF- $\mathrm{kB}$. The latter is a transcription factor for iNOS expression as well, thereby leading to reduction by Ghrelin therapy. INOS causes apoptosis through activation of the intrinsic pathway involving apoptosome formation and caspase-3 activation [49]. 


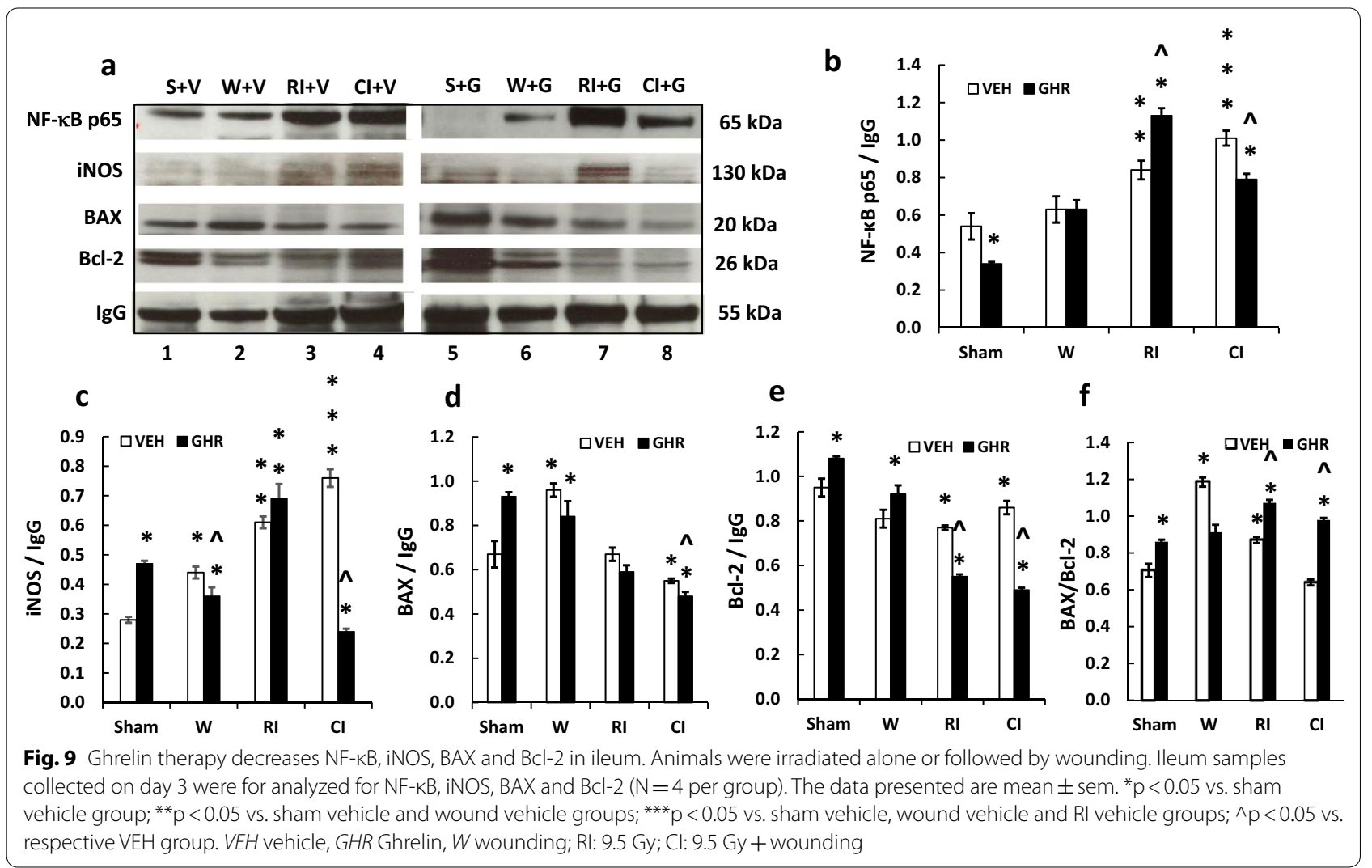

Ghrelin therapy significantly diminished BAX in CI mice, which is desirable as a therapy. BAX is known to be regulated by the free p 53 which is not conjugated by $\mathrm{mdm} 2$ [1]. The possibility of Ghrelin therapy to increase MDM2 (that can be stimulated by AKT activation) to conjugate with p53 [64], thus, leading to lower p53 in ileum cannot be excluded. Unlike BAX, Ghrelin therapy also attenuated $\mathrm{Bcl}-2$, which is not beneficial as a therapy. Bcl-2 in cultured cells [69] and in C57BL/6 mice, Fabp/-Bcl-2 mice [70] and Sprague-Dawley rats [71] manifested one band using the immunoblotting technique. However, in our B6D2F1 mice, the ileum samples exhibited two bands closed to each other, suggesting presence of unphosphorylated Bcl-2 (lower band) and phosphorylated Bcl-2 (upper band). Moreover, two bands were altered together. Therefore, the Ghrelin inhibition on Bcl-2 in RI mice and CI mice needs to be further explored.

Ghrelin has been demonstrated as a countermeasure against radiation combined with sepsis [18]. Our data in CI mice (Fig. 10) are in agreement with the observation in RI rats published by Wang and colleagues [39]. We found Ghrelin therapy effectively recovered the tight junction of ileum in CI mice but not in RI mice. The discrepancy is due to (1) the female mice we studied vs. the male rats they studied and (2) mouse Ghrelin we used vs. human Ghrelin they used. It was suggested that the effect on rats was based on complex neurogenic effects of this peptide, involving with activation of the cholinergic pathway, inhibition of the sympathetic nervous system (SNS), and down-regulation of proinflammatory cytokines [41, 72, 73]. Therefore, Ghrelin's beneficial effects following irradiation combined with sepsis may have been correlated with the rebalance of dysregulated sympathetic and parasympathetic (PNS) nervous systems [72]. It is possible that ghrelin-induced improvement of survival in our $\mathrm{CI}$ model is mediated by the rebalance of cytokines, SNS, and PNS. This hypothesis requires confirmation.

Ghrelin sustained G-CSF, KC and MIP- $1 \alpha$ levels while decreasing IL-18 in ileum (Fig. 4), thereby promoting cell survival and repair of ileum injury. Ghrelin administration accelerated body weight recovery and found no edemas [35]. Figure 11 shows the possible mechanisms of RI and CI increasing miR-34a and miR696, as well as NF- $\mathrm{KB}$. Increases in NF- $\mathrm{KB}$ expression trigger cytokines and chemokines in ileum. Increases in IL-1 $\beta / 18$, IL-6, and TNF- $\alpha$ stimulate Myd88 which reduces AKT activation and elevates MAPK activation, leading to increases in apoptosis. On the other hand, increases in NF- $\mathrm{KB}$ transcribe iNOS which 


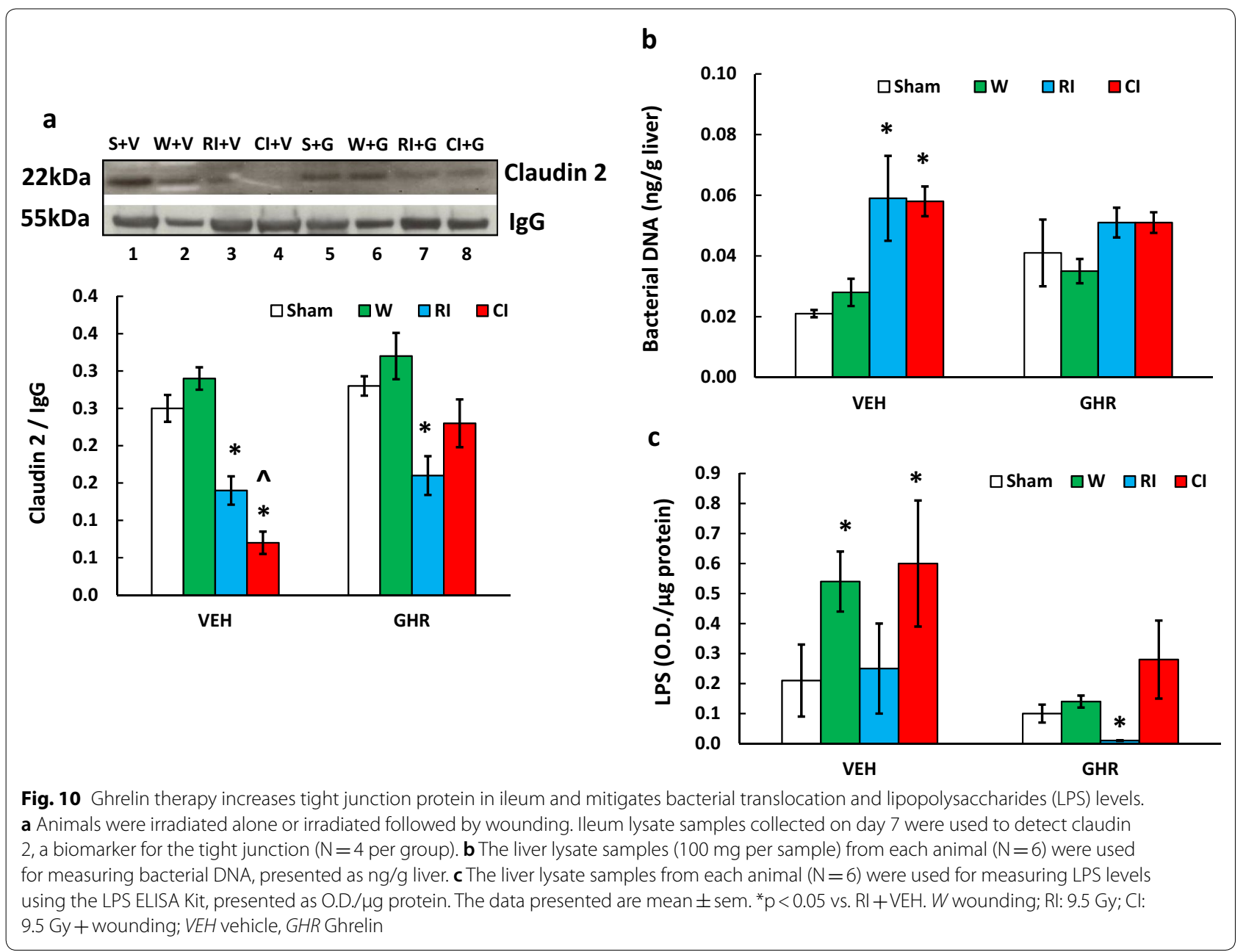

triggers caspase-3 activation resulting in apoptosis (Fig. 6). Ghrelin therapy inhibits NF-kB, reinforces RI/ $\mathrm{CI}$-induced increases in G-CSF, MIP- $1 \alpha$ and $\mathrm{KC}$ and promotes tissue repair homeostasis. This therapy also increases AKT activation, recovering the ileum tight junction (Fig. 10a) while mitigating bacterial translocation (Fig. 10b) and promoting cell survival. Moreover, increased LPS levels in wounded and CI mice but not RI mice (Fig. 10c) suggest that Gram-negative bacteria probably mainly came from wound areas. The observation is consistent with the previous report [74].

It is not clear why Ghrelin therapy was effective in inhibiting NF- $\mathrm{kB}$ and iNOS in CI mice but not in RI mice. The results suggest that NF-kB and iNOS play important roles in causing ileum injury in CI mice. In contrast, our data showed that Ghrelin therapy decreased JNK activation in RI mice but not in CI mice, suggesting JNK probably plays a significant role in RI mice (Fig. 8c). It warrants further exploration in understanding the differential effects of Ghrelin therapy after RI and CI.
Ghrelin therapy is effective for increasing survival in rats exposed to radiation alone [39] or radiation combined with sepsis [18] and in mice exposed to radiation followed by skin wounding or burning [28]. This improvement is attributed, at least in part, by mitigation of bone marrow injury [40] and intestinal injury, as presented in this report. To further confirm the contribution of Ghrelin therapy to mitigating intestinal injury, it is ideal to have a mouse model with bone marrow transplantation [11] or partial shield of bone marrow to preserve bone marrow [75] first then followed by local irradiation to the abdomen focusing on intestine. Then, the intestinal injuries can be investigated thoroughly. With it, potential medical countermeasures to treat intestinal injuries can be identified, which is this study's ultimate goal.

\section{Conclusion}

Skin wounds enhances CI-induced ileum injury, as indicated by increases in villus edema, decreases in crypt depth and crypt counts, as well as increases in 


\section{Possible Mechanisms in Ileum}

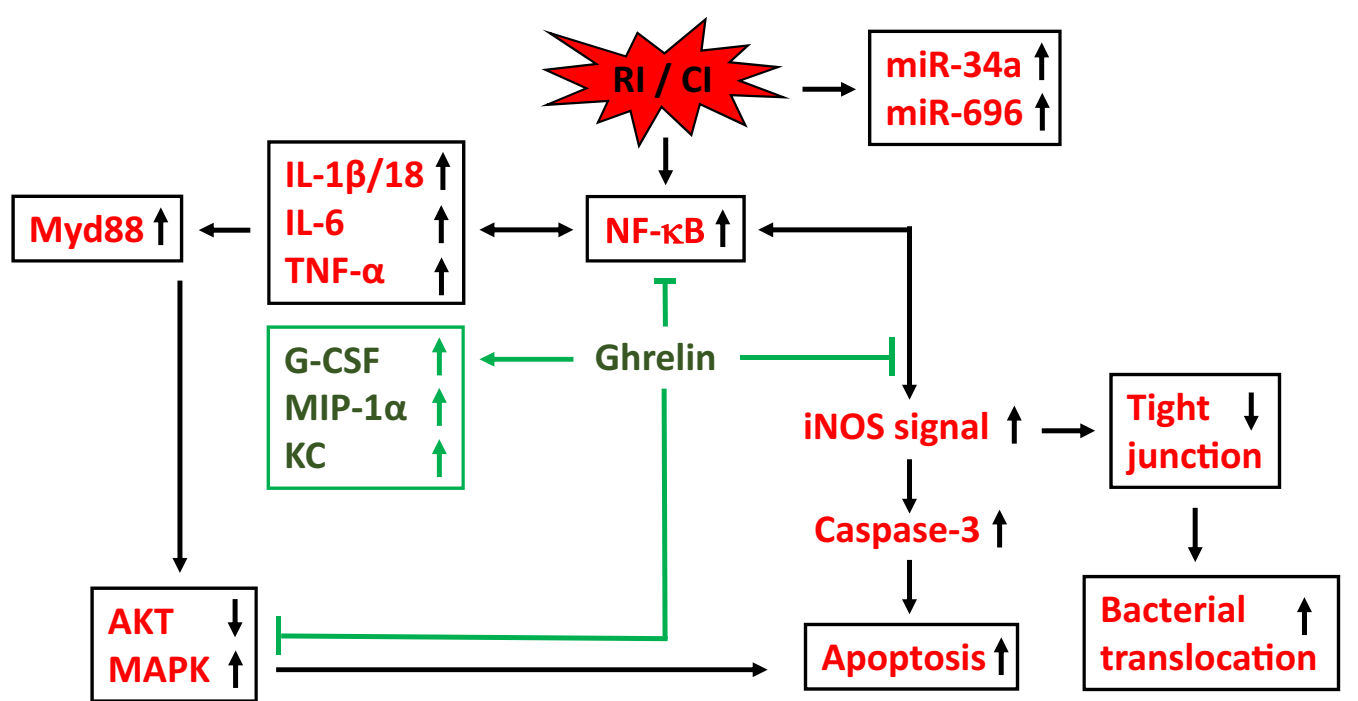

Fig. 11 Possible mechanisms of Ghrelin therapy in mitigating ileum injury. RI and Cl increase miR-34a and miR-696, as well as NF-kB. Increases in NF-KB expression trigger cytokines and chemokines in ileum. Increases in IL-1 $\beta / 18$, IL-6, and TNF-a stimulate Myd88, which reduces AKT activation and elevates MAPK activation, thereby increasing apoptosis. On the other hand, increases in NF-KB transcribe iNOS that triggers caspase-3 activation, also resulting in apoptosis. Ghrelin therapy inhibits NF-KB, reinforces RI/Cl-induced increases in G-CSF, MIP-2 and KC and promotes tissue repair. This therapy also increases AKT activation which promotes cell survival

mucosal injury scores, all of which are mitigated by Ghrelin therapy. This alleviation was confirmed by significant increases in G-CSF, KC and MIP- $1 \alpha$, decreases in IL-1 $\beta, \mathrm{IL}-6, \mathrm{IL}-18$, TNF- $\alpha$ and caspase- 3 activation, increases in AKT and ERK activation and decreases in iNOS and BAX in ileum of CI mice through NF- $\mathrm{KB}$ inhibition. The recovery of ileum function is manifested by recovery of tight junction and reduction of bacterial translocation. These results demonstrate Ghrelin's efficacy as a potential radiomitigator and radiotherapy agent for treating CI.

\footnotetext{
Abbreviations

AFRRI: Armed forces radiobiology research institute; AKT: Protein kinase B (specific for serine/threonine phosphorylation); $\mathrm{BAX}$ : BCl-2-associated X protein; BCl-2: B-cell lymphoma 2; Cl: Combined injury; ERK: Extracellular signal-regulated kinase; G-CSF: Granulocyte-colony stimulating factor; GHSR: Growth hormone secretagogue receptor; iNOS: Inducible nitric oxide synthase; i.v.: Intravenous; JNK: c-Jun N-terminal kinase; KC: Keratinocyte chemoattractant; MAPK: Mitogen-activated protein kinase; MDM2: Mouse double minute 2 homolog; p38: Protein 38; p53: Protein 53; p.o.: per os; RCI: Radiation combined injury; Rl: Radiation injury; s.c.: Subcutaneous; TBSA: Total body surface area; VSD: Veterinary science department; W: Wound.
}

\section{Acknowledgements}

The authors gratefully acknowledge the Veterinary Sciences Department staff for animal care and complete blood counts and histology slides, Dr. Vitaly Nagy and Radiation Dosimetry staff for conducting whole-body irradiation.

\begin{abstract}
Authors' contributions
JGK conceived and designed the experiments in the manuscript. JGK, JTS, GC, MNA, MZ and WC performed the experiments. JGK, JTS, GC, CH, WC and MX analyzed data and plotted the graphs for figures. JGK wrote the manuscript. All authors edited the manuscript. All authors read and approved the final manuscript.
\end{abstract}

\section{Funding}

Research was supported by NIH/NIAID YI-Al-5045-04 to JGK and AFRRI RAB32164, RAB33529 and RBB34363 to JGK.

\section{Availability of data and materials}

All relevant data are within this published paper.

Ethics approval and consent to participate

The animal experiment was approved by the AFRRI IACUC. The IACUC protocol number was 2013-12-015 with Biosample Sharing Request Approval.

\section{Consent for publication}

The publication was approved by the Armed Forces Radiobiology Research Institute, the Uniformed Services University of the Health Sciences. The views, opinions, and findings contained in this report are those of the authors and do not reflect official policy or positions of the Armed Forces Radiobiology Research Institute, the Uniformed Services University of the Health Sciences, the National Institute of Allergy and Infectious Diseases, the Department of Defense, or the United States government. The commercial products identified in this manuscript do not imply recommendation or endorsement by the federal government and do not imply that the products identified are necessarily the best available for the purpose.

\section{Competing interests}

The authors declare that they have no conflict of interests. 


\section{Author details}

${ }^{1}$ Scientific Research Department, Armed Forces Radiobiology Research Institute, Bethesda, MD 20814, USA. ${ }^{2}$ Department of Pharmacology and Molecular Therapeutics, Uniformed Services, University of the Health Sciences, Bethesda, MD 20814, USA. ${ }^{3}$ Department of Medicine, Uniformed Services, University of the Health Sciences, Bethesda, MD 20814, USA. ${ }^{4}$ Department of Biochemistry, University of California, Berkeley, CA 94720, USA.

\section{Received: 10 October 2019 Accepted: 4 May 2020} Published online: 12 May 2020

\section{References}

1. Kiang JG, Olabisi AO. Radiation: a poly-traumatic hit leading to multiorgan death. Cell Biosci. 2019;9:25.

2. DiCarlo AL, Hatchett RJ, Kaminski JM, Ledney GD, Pellmar TC, Okunieff P, Ramakrishnan N. Medical countermeasures for radiation combined injury: radiation with burn, blast, trauma and/or sepsis. Report of an NIAID Workshop, March 26-27. Radiat Res. 2008;169:712-21.

3. lijima S. Pathology of atomic bomb casualties. Acta Pathol Jpn. 1982;32(Suppl. 2):237-70.

4. Kishi HS. Effects of the "special bomb": recollection of a neurosurgeon in Hiroshima. Neurosurgery. 2000:47:441-6.

5. Barabanova AV. Significance of beta-radiation skin burns in Chernobyl patients for the theory and practice of radiopathology. Vojnosanit Pregl. 2006;63:477-80

6. Kiang JG, Jiao W, Cary LH, Mog SR, Elliott TB, Pellmar TC, Ledney GD. Wound trauma increases radiation-induced mortality by increasing iNOS, cytokine concentrations, and bacterial infections. Radiat Res. 2010;173:319-32.

7. Kiang JG, Garrison BR, Burns TM, Zhai M, Dews IC, Ney PH, Fukumoto R, Cary LH, Elliott TB, Ledney GD. Wound trauma alters ionizing radiation dose assessment. Cell Biosci. 2012;2:20.

8. Kiang JG, Ledney GD. Skin injuries reduce survival and modulate corticosterone, c-reactive protein, complement component 3, lgM, and prostaglandin E2 after whole-body reactor-produced mixed field ( $n+-$ Photons) irradiation. Oxid Med Cell Longev. 2013;2013:821541.

9. Kiang JG, Zhai M, Liao P-J, Bolduc DL, Elliott TB, Gorbunov NV. Pegylated G-CSF inhibits blood cell depletion, increases platelets, blocks splenomegaly, and improves survival after whole-body ionizing irradiation but not after irradiation combined with burn. Oxid Med Cell Longev. 2014;2014:481392.

10. Kiang JG, Fukumoto R. Ciprofloxacin increases survival after ionizing irradiation combined injury: $\gamma$-H2AX formation, cytokine/chemokine, and red blood cells. Health Phys. 2014;106:720-6.

11. Ledney GD, Elliott TB. Combined injury: factors with potential to impact radiation dose assessments. Health Phys. 2010;98:145-52.

12. Ledney GD, Elliott TB, Moore MM. Modulations of mortality by tissue trauma and sepsis in mice after radiation injury. In The Biological Basis of Radiation Protection Practice (K.L. Mossman and W.A. Mills, Eds.), pp. 202-217. Williams and Wilkins, Baltimore, 1992.

13. Ledney GD, Stewart DA, Exum ED, Sheehy PA. Skin wound-enhanced survival and myelocytopoiesis in mice after whole-body irradiation. Acta Radiol Oncol. 1981;20:29-38.

14. Palmer JL, Deburghgraeve CR, Bird MD, Hauer-Jensen M, Kovacs EJ. Development of a combined radiation and burn injury model. J Burn Care Res. 2011;32:317-23.

15. Kiang JG, Smith JT, Anderson MN, Swift JM, Gupta P, Balakathiresan N, Maheshwari RK. Hemorrhage exacerbates radiation effects on survival, leukocytopenia, thrombopenia, erythropenia, bone marrow cell depletion and hematopoiesis, and inflammation-associated microRNAs expression in kidney. PLoS ONE. 2015;10:e0139271.

16. Kiang JG, Smith JT, Anderson MN, Elliott TB, Gupta P, Balakathiresan N, Maheshwari RK, Knollmann-Ritschel B. Hemorrhage enhances cytokine, complement component 3, and caspase-3, and regulates microRNAs associated with intestinal damage after whole-body gamma-irradiation in combined injury. PLOS ONE. 2017;12:e0184393.

17. Alpen EL, Sheline GE. The combined effects of thermal burns and whole-body $x$ - radiation on survival time and mortality. Ann Surg. 1954;140:113-8
18. Shah KG, Wu R, Jacob A, Blau SA, Ji Y, Dong W, Marini CP, Ravikumar TS, Coppa GF, Wang P. Human ghrelin ameliorates organ injury and improves survival after radiation injury combined with severe sepsis. Mol Med. 2009;15:407-14.

19. Valeriote FA, Baker DG. The combined effects of thermal trauma and X-irradiation on early mortality. Radiat Res. 1964;22:693-702.

20. Korlof B. Infection of burns, I. A bacteriological and clinical study of 99 cases. II. Animal experiments: burns and total body x-irradiation. Acta Chiropractic Scandinavian. 1956;209:1-144.

21. Brooks JW, Evans El, Ham WT Jr, Reid JD. The influence of external body radiation on mortality from thermal burns. Ann Surg. 1952;136:533-45.

22. Reid JD, Brooks JW, Ham WT, Evans El. The influence of X-radiation on mortality following thermal flash burns: the site of tissue injury as a factor determining the type of invading bacteria. Ann Surg. 1955;142:844-50.

23. Baxter H, Drummond JA, StephensNewsham LG, Randall RG. Studies on acute total body irradiation in animals. I. Effect of streptomycin following exposure to a thermal burn and irradiation. Plastic Reconstruction Surg. 1953;12:439-45.

24. Fukumoto R, Burns TM, Kiang JG. Ciprofloxacin enhances stress erythropoiesis in spleen and increases survival after whole-body irradiation combined with skin-wound trauma. PLoS ONE. 2014;9:e90448.

25. Lausevic Z, Lausevic M, Trbojevic-Stankovic J, Krstic S, Stojimovic B. Predicting multiple organ failure in patients with severe trauma. Can J Surg. 2008:51:97-102.

26. Zou Z, Sun H, Su Y, Cheng T, Luo C. Progress in research on radiation combined injury in China. Radiat Res. 2008;169:722-9.

27. Kiang JG, Garrison BR, Gorbunov NV. Radiation combined injury: DNA damage, apoptosis, and autophagy. Adapt Med. 2010;2:1-10.

28. Kiang JG, Zhai M, Liao P-J, Elliott TB, Gorbunov NV. Ghrelin therapy improves survival after whole-body ionizing irradiation combined with wound or burn: amelioration of leukocytopenia, thrombopenia, splenomegaly, and bone marrow injury. Oxid Med Cell Longev. 2014;2014:215858.

29. Kojima M, Hosoda H, Date Y, Nakazato M, Matsuo H, Kangawa K. Ghrelin is a growth-hormone-releasing acylated peptide from stomach. Nature. 1999:402:656-60.

30. Inui A, Asakawa A, Bowers CY, Mantovani G, Laviano A, Meguid MM, Fujimiya M. Ghrelin, appetite, and gastric motility: the emerging role of the stomach as an endocrine organ. FASEB J. 2004;18:439-56.

31. Baatar D, Patel $K$, Taub DD. The effects of ghrelin on inflammation and the immune system. Mol Cell Endocrinol. 2011;340:44-58.

32. Kabil NN, Seddiek HA, Yassin NA, Gamal-Eldin MM. Effect of ghrelin on chronic liver injury and fibrogenesis in male rats: possible role of nitric oxide. Peptides. 2014;52:90-7.

33. $\mathrm{Xu} \mathrm{X}$, Jhun $\mathrm{BS}, \mathrm{Ha} \mathrm{CH}$, Jin ZG. Molecular mechanisms of ghrelinmediated endothelial nitric oxide synthase activation. Endocrinology. 2008;149:4183-92.

34. Chen X, Chen Q, Wang L, Li G. Ghrelin induces cell migration through GHSR1a-mediated PI3K/Akt/eNOS/NO signaling pathway in endothelial progenitor cells. Metabolism. 2012;62:743-52.

35. Gorbunov NV, Kiang JG. Ghrelin therapy decreases incidents of intracranial hemorrhage in mice after whole-body ionizing irradiation combined with burn trauma. Int J Mol Sci. 2017;18:E1693.

36. Peng Z, Zhu Y, Zhang Y, Wilhelmsen K, Jia C, Jin J, Xue Q, Feng X, Zhang F, Yu B. Effects of ghrelin on pulmonary NOD2 mRNA expression and NF-KB activation when protects against acute lung injury in rats challenged with cecal ligation and puncture. Int Immunopharmacol. 2012;13:440-5.

37. Ogura Y, Inohara N, Benito A, Chen FF, Yamaoka S, Nunez G. Nod2, a Nod1/Apaf-1 family member that is restricted to monocytes and activates NF-kappaB. J Biol Chem. 2001;276:4812-48.

38. Dixit VD, Yang H, Cooper-Jenkins A, Giri BB, Patel K, Taub DD. Reduction of T cell-derived ghrelin enhances proinflammatory cytokine expression: implications for age-associated increases in inflammation. Blood. 2009;113:5202-5.

39. Wang Z, Yang WI, Jacob A, Aziz M, Wang P. Human Ghrelin mitigates intestinal injury and mortality after whole body irradiation in rats. PLoS ONE. 2015;10:e0118213.

40. Kiang JG, Anderson MN, Smith JT. Ghrelin therapy sustains granulocyte colony-stimulating factor and keratinocyte factor to mitigate hematopoietic syndrome and spleen after whole-body ionizing irradiation combined with wound. Cell Biosci. 2018:8:27. 
41. Cheyuo C, Wu R, Zhou M, Jacob A, Coppa G, Wang P. Ghrelin suppresses inflammation and neuronal nitric oxide synthase in focal cerebral ischemia via the vagus nerve. Shock. 2011;35:258-65.

42. Montgomery CA. Oncologic and toxicologic research: alleviation and control of pain and distress in laboratory animals. Cancer Bulletin. 1990;42:230-7.

43. Tomasivic SP, Coghlan LG, Gray KN, Mastromarino AJ, Travis EL. IACUC evaluation of experiments requiring death as an end point: A cancer center's recommendations. Lab Animal. 1988 January/February; pp. 31-34.

44. International Standardization Organization and ASTM International. Standard Practice for Use of an Alanine-EPR Dosimetry System.-ISO/ ASTM International Standard 51607-2013(E)-Geneva: ISO and West Conshohocken (US:PA): ASTM International, 7 pages, 2013.

45. Kiang JG, Zhai M, Bolduc DL, Smith JT, Anderson MN, Ho C, Lin B, Jiang S. Combined therapy of pegylated-G-CSF and Alx4100TPO improves survival and mitigate acute radiation syndrome after whole-body ionizing irradiation alone and followed by wound trauma. Radiat Res. 2017; 188:476-90

46. Han JM, Kim HG, Lee JS, Choi MK, Kim YA, Son CG. Repeated sense of hunger leads to the development of visceral obesity and metabolic syndrome in a mouse model. PLoS ONE. 2014;9(5):e98276.

47. Banerjee S, Fu Q, Shah SK, Meinyk SB, Sterneck E, Hauer-Jensen M, Pawar SA. C/EBPdelta protects from radiation-induced intestinal injury and sepsis by suppression of inflammatory and nitrosative stress. Sci Rep. 2019;9:13953.

48. Kiang JG, Smith JT, Hegge SR, Ossetrova N. Circulating cytokine/ chemokine concentrations respond to ionizing radiation doses but not radiation dose rates: granulocyte-colony stimulating factor and interleukin-18. Radiat Res. 2018;189:634-43.

49. Kiang JG, Smith JT, Agravante NG. Geldanamycin analog 17-DMAG inhibits iNOS and caspases in gamma irradiated human T cells. Radiat Res. 2009;172:321-30.

50. Kiang JG. Inducible heat shock protein $70 \mathrm{kD}$ and inducible nitric oxide synthase in hemorrhage/resuscitation-induced injury. Cell Res. 2004;14:450-9.

51. Hei TK, Zhou H, Chai Y, Ponnaiya B, Ivanov VN. Radiation induced non targeted response: mechanism and potential clinical implications. Curr Mol Pharmacol. 2011;4:96-105.

52. Williams JP, Brown SL, Georges G, Hauer-Jensen M, Hill RP, Huser AK, Kirsch DG, MacVittie TJ, Mason KA, Medhora MM, Moulder JE, Okunieff P, Otterson MF, Robbins ME, Smarthers JB, McBride WH. Animal models for medical countermeasures to radiation exposure. Radiat Res. 2010;173:557-78

53. Park $\mathrm{I}-\mathrm{H}$, Song $\mathrm{Y}-\mathrm{S}$, Joo H-W, Shen G-Y, Seong J-H, Shin N-K et al. Role of microRNA-34a in anti-apoptotic effects of granulocyte-colony stimulating factor in diabetic cardiomyopathy. Diab Metab J Published online Apr 23, 2019.

54. Li L, Han X, Gao Y, Diao Q, Xiao Y. Ethanol extract of Gynura bicolor (GB) protects against UVB-induced photodamage of skin by inhibiting P53-mediated Bcl-2/BAX/Caspase-3 apoptosis pathway. Arch Dermatol Res. 2019. https://doi.org/10.1007/s00403-019-01977-y [Epub ahead of print].

55. lida N, Grotendorst GR. Cloning and sequencing of a new gro transcript from activated human monocytes: expression in leukocytes and wound tissue. Mol Cell Biol. 1990;10:5596-9.

56. Becker S, Quay J, Koren HS, Haskill JS. Constitutive and stimulated MCP-1, GRO alpha, beta, and gamma expression in human airway epithelium and bronchoalveolar macrophages. Am J Physiol. 1994;266:L278-86.

57. Devalaraja RM, Nanney LB, Du J, Qian Q, Yu Y, Devalaraja MN, Richmond A. Delayed wound healing in CXCR2 knockout mice. J Invest Dermatol. 2000;115:234-44.

58. Nakamura A, Shikata K, Hiramatsu M, Nakatou T, Kitamura T, Wada J, Itoshima T, Makino H. Serum interleukin-18 levels are associated with nephropathy and atherosclerosis in Japanese patients with type 2 diabetes. Diab Care. 2005;28:2890-5.
59. Italiani P, Puxeddu I, Napoletano S, Scala E, Melillo D, Manocchio S, AngioIillo A, Migliorini P, Boraschi D, Vitale E, Di Costanzo A. Circulating levels of IL-1 family cytokines and receptors in Alzheimer's disease: new markers of disease progression? J Neuroinflamm. 2018;15:342

60. Xiao M, Li X, Hull L, Cui. Interleukin-18 binding protein (IL-18BP) mitigates radiation injury in mice. Radiation Research Society Annual Meeting Abstract Book, p70, 2019.

61. Maurer M, von Stebut E. Macrophage inflammatory protein-1. Int J Biochem Cell Biol. 2004;36:1882-6.

62. Kiang JG. Exacerbation of mild hypoxia on acute radiation syndrome and subsequent mortality. Adaptive Med. 2017;9:28-33.

63. Huang CY, Yu LC. Pathophysiological mechanisms of death resistance in colorectal carcinoma. World J Gatroenterol. 2015;7:11777-92.

64. Kiang JG, Smith JT, Anderson MN, Umali MV, Ho C, Zhai M, Lin B, Jiang S. A novel therapy, using ghrelin with pegylated G-CSF, inhibits brain hemorrhage from ionizing radiation or combined radiation injury. Pharm Pharmacol Int J. 2019;7:133-45.

65. Meng F, Liu L, Chin PC, D'Mello SR. Akt is a downstream target of NF-KB. J Biol Chem. 2002;277:29674-80.

66. Kandel ES, Hay N. The regulation and activities of the multifunctional serine/threonine kinase Akt/PKB.Exp. Cell Res. 1999;253:210-29.

67. Brazil DP, Hemmings BA. Ten years of protein kinase B signaling: a hard Akt to follow. Trends Biochem Sci. 2001;26:657-64.

68. Scheid MP, Woodgett JR. PKB/AKT: functional insights from genetic models. Nat Rev Mol Cell Biol. 2001:2:760-8.

69. Kiang JG, Garrison BR, Smith JT, Fukumoto R. Ciprofloxacin as a potential radio-sensitizer to tumor cells and a radio-protectant for normal cells: differential effects on $\mathrm{\gamma}$-H2AX formation, p53 phosphorylation, $\mathrm{BCl}-2$ production, and cell death. Mol Cell Biochem. 2014;393:133-43.

70. Coopersmith CM, O'Donnell D, Gordon JI. BCl-2 inhibits ischemia-reperfusion-induced apoptosis in the intestinal epithelium of transgenic mice. Am J Physiol. 1999;276(3):677-86.

71. Koppelmann T, Pollak Y, Mogilner J, Bejar J, Coran AG, Sukhotnik I. Dietary L-arginine supplementation reduces methotrexate-induced intestinal mucosal injury in rat. BMC Gastroenterol. 2012;12:41.

72. Jacob A, Shah KG, Wu R, Wang P. Ghrelin as a novel therapy for radiation combined injury. Mol Med. 2010;16:137-243.

73. Stoyanova II. Ghrelin: Expression and Functions in the Central Nervous System. In: Ghrelin: Production, Action Mechanisms and Physiological Effects. Nova Science Publishers, Inc, USA, pp. 57-75. ISBN 978-1-61942400-5, 2011.

74. Elliott TB, Ledney GD, Harding RA, Henderson PL, Gerstenberg HM, Rotruck JR, Verdolin MH, Stille CM, Krieger AG. Mixed-field neutrons and gamma photons induce different changes in ileal bacteria and correlated sepsis in mice. Int J Radiat Biol. 1995;68:311-20.

75. Booth C, Tudor G, Tonge N, Shea-Donohue T, MacVittie TJ. Evidence of delayed gastrointestinal syndrome in high-dose irradiated mice. Health Phys. 2012;103:400-10.

\section{Publisher's Note}

Springer Nature remains neutral with regard to jurisdictional claims in published maps and institutional affiliations.

Ready to submit your research? Choose BMC and benefit from

- fast, convenient online submission

- thorough peer review by experienced researchers in your field

- rapid publication on acceptance

- support for research data, including large and complex data types

- gold Open Access which fosters wider collaboration and increased citations

- maximum visibility for your research: over 100M website views per year

At BMC, research is always in progress.

Learn more biomedcentral.com/submissions 